\title{
3 The Philosophie Sociale of 1793: A New Thought
}

\subsection{The Philophie Sociale of 1793}

In this second chapter I will delve into the Philosophie sociale, on which Moses Dobruska began to work feverishly, in Paris, towards the end of 1792. In all likelihood, Dobruska wrote the first version of the opus in German. Of this Urauffassung only a few sheets remain: these were among the papers seized from the author at the time of his arrest in November 1793 and were then deposited at the Archives nationales of Paris. The German text, which I am publishing for the first time here in the appendix, and which I will quote where the pages are available, although limited to a small part of the work, is very significant. It shows us how much Dobruska was deeply immersed in the German culture of his time, and how the Philosophie sociale, composed in France and so closely linked to French politics and the Revolution, has a fundamental German intellectual component.

\subsection{The Title}

First and foremost, the title deserves our attention. Although he is not the inventor of the expression "social philosophy", ${ }^{67}$ Dobruska certainly has a good claim to be considered the first great promoter of the union between philosophy, the symbol of Enlightenment, and the social sphere. As I already mentioned, Jean-Baptiste Durosoy, a Jesuit from Belfort, in Bourgogne-Franche-Comté, had already published a work entitled Philosophie sociale ou essai sur les devoirs de l'homme et du

\footnotetext{
67 Axel Honneth's statement that Thomas Hobbes coined the term "social philosophy" does not seem to be justified: "Wenn es auch Thomas Hobbes war, der an der Mitte des 17". Pathologien des Sozialen. Die Aufgaben der Sozialphilosophie, ed. Axel Honneth (Frankfurt am Main: Fischer, 1994), 11, which in note - ibidem 63 - refers to Leviathan). In Leviathan Hobbes speaks only of "civil philosophy", in reference to ancient philosophy, from which he distances himself: "and for their moral and civil philosophy, it hath the same or greater absurdities", see Thomas Hobbes, Leviathan (London: Crooke, 1651), 455.
}

○ Open Access. (C) 2022 Silvana Greco, published by De Gruyter. (cc)BY This work is licensed under the Creative Commons Attribution 4.0 International License. 
citoyen in $1783 .^{68}$ This book was reprinted several times (1822, 1843) and was also translated into German in $1852 .^{69}$

The assumption from which Durosoy starts is that the human being was born for society, to be together with his fellow human beings. There are no human beings who live isolated as individual atoms. Not only does man seek the company of his fellow human beings, but he also wants to set a "good example" for them, even though there are people whose way of relating to others does not represent a good example to follow.

Durosoy mentions, among these negative cases, individuals who give themselves to luxury, the corrupt, the spouses who never exchange affection, the fathers who do not take care of their children, etc., as well as those who do not take care of their children. The objective of his social philosophy is to provide a well articulated mapping of duties and rules of conduct to be followed in relation to society and its members. In addition, Durosoy identifies a list of specific

68 Jean-Baptiste Durosoy, Philosophie sociale ou essai sur les devoirs de l'homme et du citoyen (Paris: C.P. Berton, 1783). According to the frontispiece, Durosoy was "abbot, professor of philosophy, doctor and professor of theology, ecclesiastical advisor of his Highness the PrinceBishop of Basel”. Some details about Jean-Baptiste Durosoy in Jean Joseph C. D[escharrères], Essai sur l'histoire littéraire de Belfort et du voisinage (Belfort: J. P. Clerc, 1808), 16-18; Note de la Direction at the foot of the "Vie de Monseigneur Casimir-Fréderic des Baraons de Rathsamhausen”, also written by Descharrères, in Revue d'Alsace 10 (1859), 347-348. I drew attention to the antecedent, represented by Durosoy's Philosophie sociale, for the first time in Silvana Greco, Heresy, Apostasy, and the Beginnings of Social Philosophy. Moses Dobruska reconsidered, in "Materia giudaica" 20-21 (2015-2016), pp. 439-464, esp. 14. Franck Fischbach, Manifeste pour une philosophie sociale (Paris: La Decouverte 2009), 19, was not aware of it when he wrote that the expression "social philosophy" was first used by our Dobruska/Frey (see also the German version: Idem, Manifest für eine Sozialphilosophie, transl., Lilian Peter, with an afterword by Thomas Bedorf und Kurt Röttgers (Bielefeld: Transcript, 2016), 20. Ibidem, 141 the two editors of the German edition, correcting Fischbach, cite Durosoy and refer to "recent research" for clarification, without explicitly naming their source: "Das [i.e. the Philosophie sociale of Dobruska / Frey] ist zwar nicht die erste Erwähnung, die erste war eine quasi-rousseauistische "Ethik" des elsässischen Abbé Durosoy, wie jüngere Forschungen ergeben haben").

69 Jean Baptiste Durosoy, Der christliche Weltbürger oder Grundsätze des socialen Lebens ein Versuch über unsere Pflichten als Menschen und Staatsbürger (Münster: Theissing, 1852). Cfr. anche Adolph L. H. Geck, "Die Aufgaben einer Christlichen Gesellschaftslehre als einer Wissenschaftlichen Disziplin,” Jahrbuch für christlichen Sozialwissenschaften 11 (1970): 262, which, however, gives, for the original French edition the date 1793, clearly confusing the work of Abbé Durosoy, published in 1783, with that of our Dobruska. 
duties that man should follow in the various stages of the cycle of his life in which he assumes different social roles, such as that of spouse and family man. ${ }^{70}$

In fact, the book by Durosoy doesn't propose a veritable "social philosophy”, as Dobruska began to characterize it and as it was later developed from the nineteenth century until today, especially in the German context. What's more, Durosoy's work is an extensive collection of ethical precepts meant to be useful in living "well” in society, without, however, specifying this well-being more clearly.

\subsection{Purposes and Structure}

The Philosophie sociale has three core purposes.

First, Dobruska wants to deepen our knowledge, which he hopes will become scientific in the future, of the individual and society. It is the society of the Ancien Régime, but also the democratic one, still in the making. As he intends it, the future democratic society must aim to achieve the happiness of individuals and the community. ${ }^{71}$ Only a deep understanding of human nature, of acting in society and of the social structure as a whole, allows us to define concepts such as "individual", "society", "freedom", "equality", etc., and to elaborate, on the basis of them, rules and norms of action, termed "principles" (principes) by Dobruska.

Secondly, the Philosophie sociale intends to propose a philosophical and critical reflection on the society of the Ancien Régime, underlining the "monstrous mixtures" (mélanges monstreux) that must be overcome through a process of "social disorganization". As I already pointed out, in the parlance of today's scientific investigation we could match Dobruska's mélanges to the "social pathologies" of Axel Honneth. ${ }^{72}$

Thirdly, the book draws up a universal constitution for the French people, which contains seventy principles, to be understood as rules and standards of action, for the formation of a representative democratic society.

70 Durosoy, Philosophie sociale ou essai sur les devoirs de l'homme et du citoyen, 1-6.

71 Dobruska, Philosophie sociale, vi.

72 Honneth, Pathologien des Sozialen, 51: [Was als sozialer Mißstand gilt, liegt demnach nicht einfach auf der Ebene der Verletzung von Gerechtigkeitsgrundsätzen; vielmehr sollen Störungen kritisiert werden, die mit psychischen Krankheiten die Eigenschaft teilen, daß sie die Lebensmöglichkeiten einschränken oder deformieren, die als ,normal‘ oder ,gesund“ vorausgesetzt werden]. 
These principles concern, on the one hand, man, his intellectual and moral faculties, his way of relating to other members of society, and his rights, as well as his duties towards other citizens and towards society and the State. On the other hand, the principles are addressed to society, its property, its rights and duties towards citizens, and the powers of the State, necessary to govern society itself (see Appendix 2).

It will be the task of the representatives of the French people to draw up the body of legislation and define the institutions and their regulations, on the basis of the principles contained in the first part of the Constitution. This process of applying the principles constitutes the second part of the Constitution.

Dobruska himself indicates three parts into which his work is divided.

The first part of the essay is what he calls the "revolutionary" one - at once a critique and a predictable target of criticism:

so that I could establish and build, it was necessary for me to overturn and secure some land on which to erect my building. I could define this first part of my work as the revolutionary part, which will certainly be the subject of more or less philosophical counter-revolutionary criticism. ${ }^{73}$

The second part focuses on the "essence and form" of the Constitution of the nascent democratic society, after the collapse of the Ancien Régime. Dobruska would like to point out that this part of the reflection is often neglected in philosophical treatises. It is precisely in order to remedy this shortcoming that Philosophie sociale is spreading about the ethical principles and social and institutional practices on which the Constitution must be based.

The third and final part of the work is the constituent one, in which the fundamental themes to be contained in the Universal Constitution and its principles are elaborated..$^{74}$

This is the succession of the three parts (see Fig. 1):

Part One: Research on some of the main themes of social philosophy

Part Two: On the essence of a Constitution and its form

Part Three: Universal Constitution

73 Dobruska, Philosophie sociale, XII: [La première partie de cet ouvrage est une discussion abrégée de quelques préjugés de cette espèce; car avant de bâtir et de construire, il a fallu que je renversasse et que j'assurasse en quelque sorte le terrein sur lequel je voulois élever mon édifice. Je pourrois nommer cette pre-mière partie, la partie révolutionnaire de mon ouvrage, qui s'attend, à coups sûrs, à des chocs contre-révolutionnaires plus ou moins philosophiques]. 74 Ibidem. 


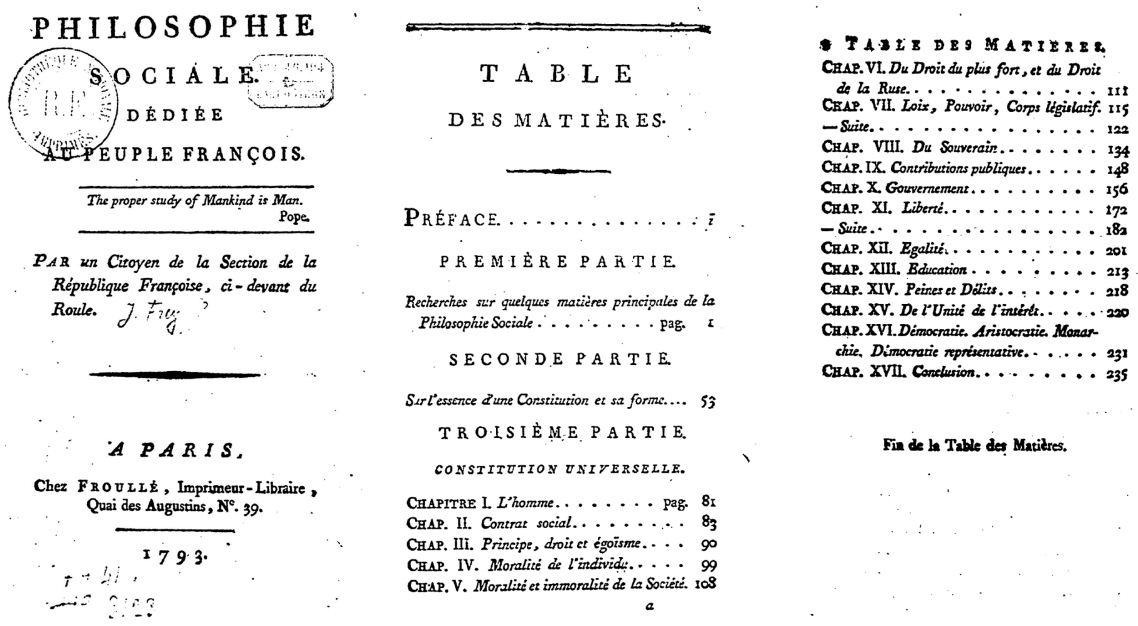

Fig. 1: Frontispiece and Table of Contents of the Philosophie sociale, dédiée au peuple françois (1793).

\subsection{Recipients of the Philosophie Sociale}

As we begin to flip through the book, we can ask ourselves who the recipients are. There is one collective recipient, namely the French people, and one more particular one, namely the so-called "decent people".

The full title of the book is revealing: Philosophie sociale dédiée au peuple françois (Social philosophy dedicated to the French people).

The principal addressees of the work are, however, les gens de bien, i.e. people who are capable of critical thinking, of judging with their own rational faculties, who do not recognize any other authority, in the republic of letters, outside the truth and who are not seduced by superstition or even less by prejudices. This is the tone of the dedication at the beginning of the volume:

I dedicate this work to all good people, exempt from all literary glory, who are not prevented prejudiced,and who are without school superstition. I dedicate it to the tribunal of men, who think and judge for themselves and who do not recognize any authority in the republic of letters outside the truth; and who love the truth for the truth, no matter the book in which they find it; no matter the licenses and vigor with which prejudices are broken down, supported by the powerful protection of great men; for there are profound 
and erudite prejudices but also superficial prejudices, foolish and vulgar, which seduce and fascinate the heart. ${ }^{75}$

\subsection{Distinction Between State and Society}

From this synthetic scheme, one can already understand how Dobruska's thought cannot be reduced to a mere "political philosophy" and, in particular, to a simple draft of a Constitution, necessary after the French Revolution, as was until now supported on the basis, I believe, of only a shallow examination of the Philosophie sociale. $^{76}$

The fact that this is not just a simple political philosophy can be seen not only from the wealth of topics covered but also from the more general theoretical approach. ${ }^{77}$

In a broad sense, the object of study of classical political philosophy, from Greek thinkers to, one can say, today, is "political life", as an expression of the dynamics between groups confronting each other to gain power within a community. In a narrower sense, political philosophy deals with so-called "political foundations" which are made up of two types of categories, according to Leo Strauss' acute definition. On the one hand, the "nature of political things", that is, the laws, institutions, actions, decisions, programs, and desires of human beings as political actors. On the other hand, the categories of the second type concern the best or fairest political order. ${ }^{78}$

Especially in the tenth and sixteenth chapters of the third part, Dobruska reflects on which is the best and most suitable political regime for the society that is emerging from the French Revolution. ${ }^{79}$ But the primary object of the

75 Dobruska, Philosophie sociale, XI-XII: [J'adresse mon ouvrage à tous les gens de bien, exempts de toute gloriole littéraire, sans prévention et sans superstition scholastique; c'est au tribunal des hommes, qui pensent et qui jugent par eux-mêmes, qui ne reconnoissent aucune autorité dans la république des lettres que la vérité, et qui ne l'aiment que pour elle, n'importe le livre où ils la trouvent, n'importe avec quelle franchise et quelle vigueur on y terrasse des préjugés soutenous de la puissance protection des grands hommes, et devenus chers à l'esprit du siècle; car il y a des préjugés profonds et érudits, qui séduisent et captivent l'esprit, comme il y a des préjugés superficiels, sots et vulgaires, qui séduisent et captivent le cœur].

76 Thomas Bedorf and Kurt Röttgers, "Einleitung," in Einführung in die Sozialphilosophie, by Franck Fischbach (Hagen: FernUniversität in Hagen 2017), 1-12.

77 Rahel Jaeggi and Robin Celikates, Sozialphilosophie. Eine Einführung (München: Beck, 2017), 7-10.

78 Leo Strauss, “On classical political Philosophy,” Social Research 12 (1945): 98.

79 Dobruska, Philosophie sociale, 31-235. 
Philosophie sociale is society and, consequently, the reorganization of a new democratic society in which citizens can be happy. With the French Revolution there came "social disorganization", and it was therefore necessary to think about "social reorganization", to reflect on how to rebuild a society, and not simply structure a state. Reconstruction and integration is, moreover, one of the recurrent themes of both social philosophy ${ }^{80}$ and sociological thought.

As noted by Rahel Jaeggi and Robert Celikates, it was precisely with the birth of modernity and the development of capitalism that modern social philosophy and attention to social issues arose. In fact, before the French Revolution, the social order was justified and legitimized as being of a divine nature. The absolute monarchy was the legitimate representative of that order. It is only with the fall of absolutism that man regains a central place in society and places himself as the creator of his own destiny.

But it is not only a different and wider object of study that distinguishes social philosophy from political philosophy. There is, in the former but not in the latter, the desire to carry out "a socio-theoretical and socio-ontological analysis of the structure and dynamics of societal circumstances". ${ }^{81}$

This desire for analysis, in which the emphasis is placed on society, on life in society and, in particular, on individuals who live and interact with each other in different social spheres, is grasped from the very beginning of Dobruska's work.

In short, there is a reversal of perspective with respect to political philosophy. It is the analysis and understanding of social reality - from individuals and their interactions to society in general - that determines the content of the Constitution, the principles of its laws, the political institutions necessary for the new society. We do not start from politics to reach society, but vice versa: social interactions determine the political structure. To use a contemporary expression, Dobruska embraces a "bottom up" vision of politics, not a "top down" one. Political institutions are a cultural and social product; they are determined by social life.

It is no coincidence that, at the very beginning of the work, Dobruska argues with Jean-Jacques Rousseau's thesis according to which the form of government best suited to a nation is also determined by its territorial dimension.

Dobruska replies that the human being always remains the same, both in a large territory and in a smaller one. As a good liberal, in fact, Dobruska embraces

80 Cf. Alessandro Ferrara, “The Idea of a Social Philosophy,” Constellations 9 (2002): 422.

81 Cf. Jaeggi, Celikates, Sozialphilosophie, 11: [eine sozialtheoretische und sozialontologische Analyse der Struktur und Dynamik gesellschaftlicher Verhältnisse]. 
methodological individualism. It is from the analysis of the individual and from the understanding of the individual understood as a social being and as a citizen (holder of rights) that one must start in order to be able to reorganize society. Political institutions are only instrumental to this broader vision of society.

\subsection{The Need for a Scientific Reflection on Social Issues}

From the very first pages of his work, Dobruska condemns the pre-existing social philosophy. "A science of rulers to betray the governed" 82 is no longer acceptable. Now is the time for a radical change in thinking, which should focus primarily on social reality and only secondarily on political institutions. In other words, we must consider the "governed", their needs and their social interaction, if we do not want to "betray" them.

Social philosophy had until then been nothing more than a poor political philosophy. To change, it is necessary to adopt not only new content, but also a different method of investigation.

In its pars destruens, the new social philosophy of Dobruska has the task of understanding and highlighting everything that did not work in the society of the Ancien Régime. In its pars construens, it aims at defining the principles capable of regulating a society in which individuals can be happy.

To achieve this ambitious goal, however, it is necessary to know the nature of human beings: "the general order of nature, the immense system of created beings". ${ }^{83}$ Therefore, Dobruska investigates not only the physical and socio-cultural context in which individuals live, as social beings, but also the way in which they interact with each other. But Dobruska does not stop there - he digs deeper into the human soul because he wants to understand its desires, motivations, and ethical and moral demands.

What do men want? How do they behave and how do they interact with each other as individuals and as members of a society? What are their moral abilities? Why are some rich and others poor? What makes man happy and what makes society as a whole happy? How have societies evolved over time?

These are the main questions that Dobruska wants to answer, elaborating a thought that he himself defines as "social art" (art social), of which we see two strands. One is properly philosophical-social, while we can rightly define the second

82 Dobruska, Philosophie sociale, VI: [La science des gouvernans pour tromper les gouvernés]. 83 Ibidem, 53 : “l'ordre général de la nature, dans l'immense systême des êtres créés”. 
strand as sociological. Social art must be rethought, down to its fundamentals, and stripped of the "miserable rags" with which it has covered itself in the past:

I decided to go down from an illusory height, to start studying again, to meditate first of all on definitions, to ask them to nature itself, to go back to that primitive source of social art, to erase from my spirit everything I had read in books, to strip myself of all those miserable rags of a wrong and pedantic politics, of an illusory and destructive social art. $^{84}$

Proud of his new clothes, which replace the theoretical "rags" of the past, Dobruska's social thinking seeks to understand the motivations of men, their behaviors and the development of society, not as they should be but as they are and as they have been realized historically: social reality must be explained in the same way as the natural world, taking inspiration from the laws and natural principles (that is, laws of cause and effect).

Dobruska's is a fundamental transformation of the "reflection on the social”, from the metaphysics that it was, into a true science: ${ }^{85}$

Social philosophy in the state in which it finds itself cannot yet strictly speaking be called a science [. . . I It was only after the successful demonstration of the equilateral triangle that mathematics rose to the level of science, and to this dignity of a safe and firm march. It is only after the happy discoveries of Galileo, Toricelli [sic] and Stahl, that physics and chemistry began to deserve the name of sciences, which opened a certain way for centuries to come. ${ }^{86}$

As in mathematics, physics, and chemistry, "social art" must discover the laws of cause and effect of its object of study. It aims to understand that truth that remains hidden from most, which has nothing to do with the opinions of individuals. In other words, Dobruska believes that "the social world, like the natural world, is governed by laws. And the former, like the latter, can be studied

84 Ibidem, VIII: [Je me suis donc déterminé à descendre d'une hauteur illusoire, à commencer à étudier de nouveau, à méditer avant tout sur les définitions, à les demander à la nature ellemême, à remonter à cette source primitive de l'art social, à effacer de mon esprit tout ce que j'avais lu dans les livres, et à me dépouiller de tous ces haillons misérables d'une politique fausse et pédantesque, d'un art social illusoire et destructeur].

85 Ibidem, IV-V.

86 Ibidem, IV-V, XIV: [La philosophie sociale dans l'état où elle se trouve, ne peut pas encore être nommée strictement et proprement une science [. . .] Ce n'est que depuis la première démonstration heureuse du triangle équilatéral, que les mathématiques se sont élévées à la hauteur d'une science, et à cette dignité d'une marche sûre et ferme. Ce n'est que depuis les heureuses découvertes de Galilei, et Toricelli et de Stahl, que la physique et la chymie ont commencé à mériter le nom de sciences, qu'elles ont frayé une route certaine aux siècles avenir]. 
objectively with the same logic of investigation and the same method". ${ }^{87}$ This is a prescient intuition, which anticipates the assumptions of positivist sociology. The study of society finally carried out using scientific methods: this is the social art of Dobruska. In the chapter on the posthumous fortune of the Philosophie sociale, we will see how, from these intuitions, Comte's "social physics" is born.

In order to arrive at the truth to which it aspires, social reflection must follow a "safe path", that is, it must adopt the tools and techniques of the natural sciences, from the formulation of definitions (which today we would call hypotheses) to the questioning of "nature", observing natural facts in order to succeed in arriving at a law, by inductive means, from the particular to the universal.

Dobruska certainly lays rudimentary foundations for what would become known in the literature in the following centuries as the positivist paradigm of the social sciences, namely "the study of social reality using the conceptual apparatus, the techniques of observation and measurement, the instruments of mathematical analysis, the procedures of inference of the natural sciences". 88

We have talked about rudimentary traits of Dobruska's works, and this is a judgment that concerns the lack of in-depth study of the criteria of scientificity. Although Dobruska believes that a scientific approach is necessary to know the social world, he does not devote a single chapter of his work to scientific methodology. In short, his declaration of scientificity is more of a declaration of principle, however brilliant, than an articulation of an adequate scientific methodology.

Having said that, a careful analysis of his Philosophie sociale reveals a methodological path which the author follows to reflect on human behavior and society in a "scientific" way. It is the way he travels in search of the social principles and rules with which to build a democratic society, in which people can be happy.

Reading between the lines we can identify three different methodological approaches, which the sociologists of the nineteenth century would go on to develop in their own writings- think first of Auguste Comte in his Cours de philosophie positive - Dobruska uses an empirical-descriptive method based on observation, a comparative method, and, finally, a historical method.

Dobruska, as a forerunner of the positivists of the nineteenth century, from whom those of the twentieth century would differ, ${ }^{89}$ implicitly postulates, on

87 Piergiorgio Corbetta, Metodologia e tecnica della ricerca sociale (Bologna: Il Mulino, 1999), 25.

88 Corbetta, Metodologia e tecnica della ricerca sociale, 24.

89 Ibidem, 23. 
an ontological level, a rather simplistic realism, whereby the social world is considered real and knowable in exactly the same way as the natural one. ${ }^{90}$ Social relations are treated as if they were "things".91

On the epistemological level, however, our author implicitly adheres to the idea, also developed by nineteenth-century positivists, of an objective separation between social reality and the researcher who studies it. The aim is to produce knowledge that takes the form of "laws, based on categories of cause and effect. They exist in the external reality independently from the observers and supervise it ('natural laws'): the task of the social scientist is to "discover them". 92

And here we see how much Dobruska's thought is influenced by Montesquieu and, in particular, his work The Spirit of the Laws. Already Montesquieu seeks to observe social reality and to infer from it laws in the form of cause and effect. He seeks to extract the causes of social phenomena.

To illustrate this, I will cite some initial and clarifying phrases from the preface of The Spirit of the Laws:

I have first of all considered mankind; and the result of my thoughts has been, that, amidst such an infinite diversity of laws and manners, they were not solely conducted by the caprice of fancy. I have laid down the first principles, and have found that the particular cases apply naturally to them; that the histories of all nations are only consequences of them; and that every particular law is connected with another law, or depends on some other of a more general extent. ${ }^{93}[$. . . ] I have not drawn my principles from my prejudices, but from the nature of things. ${ }^{94}$

90 Loc. cit.

91 It was the French sociologist Emile Durkheim, in the Rules of the sociological method (Les règles de la méthode sociologique), which appeared in 1894 in the Revue philosophique, and in book form the following year (Paris 1895), who stated that the social scientist, in particular the sociologist, should consider social facts as things: "En second lieu, notre méthode est objective. Elle est dominée tout entière par cette idée que les faits sociaux sont des choses et doivent être traités comme telles” (Durkheim, Les règles, 175).

92 Corbetta, Metodologia e tecnica, 27.

93 [Charles -Louis de] Montesquieu, Tutte le opere 1721-1754, ed., Domenico Felice (Milano: Bompiani, 2014), 896-897: [J'ai d'abord examiné les hommes, et j'ai crû que dans cette infinie diversité de loix et de mœurs, ils n'étoient pas uniquement conduits par leurs fantaisies. J'ai posé les principes, et j'ai vû les cas particuliers s'y plier comme d'eux-mêmes, les histoires de toutes les nations n'en être que les suites, et chaque loi particulière liée avec une autre loi, ou dépendre d'une autre plus générale]. Idem, The complete Works of M. de Montesquieu, Volume the First, Dublin: W. Watson, 1777, xxxvii.

94 Ibidem, . 898-899: [Je n'ai point tiré mes principes de mes préjugés, mais de la nature des choses]. Idem, The complete Works of M. de Montesquieu, Volume the First, Dublin: W. Watson, 1777 , xxxviii. 
The objective already set by the Montesquieu sociologist is partly taken up and elaborated by Dobruska, who makes use of the observation of social reality in a detached and objective way and then, in an inductive way, inferring from the particular to the general, arrives at the formulation of the law.

Let's look at two examples from his work to better clarify this "scientific procedure".

The first example concerns the law on the morality of the State, elaborated in the fifth chapter of the Philosophie sociale. On this, Dobruska states: "The morality of the State is the consequence of individual morality". ${ }^{95}$ Notice how this law has been formulated in terms of cause (individual morality) and effect (the morality of the State).

He himself explains to us in the following how he came to this theory, starting from the observation of the particular and arriving at a generalization. In the philosophical-scientific literature of the eighteenth and nineteenth centuries, the process is still fundamentally inductive, that is, "the passage from the details to the universal, the process by which from empirical observation, from the identification of regularity and recurrences in the fraction of reality empirically studied, one reaches generalizations or universal laws".96

Dobruska says:

Let me explain: if an individual has saved another from the clutches of a fierce beast, if he has saved him from the flames, if he has prevented him from being swallowed by the force of a strong wave; finally, if he has preserved his days from any imminent danger. And if society rewards this individual for this particular voluntary act, then this reward represents a moral act of the state society. ${ }^{97}$

The second example concerns his conceptualization of man. He observes that in nature all men are equal, albeit with different attitudes and abilities. It therefore makes no sense to distinguish between a social man, a political or a civil man, as the absolutist regime of Louis XVI did. In a democratic society, every man must be a citizen. The deepest motivation of every human being is the desire to achieve certain material or intellectual goals, to develop his ingenuity

95 Dobruska, Philosophie sociale, 108: [La moralité d'état est la conséquence de la moralité individuelle].

96 Corbetta, Metodologia e tecnica, 25.

97 Dobruska, Philosophie sociale, 108: [Je m'explique: si un individu en a sauvé volontairement un autre des griffes d'une bête féroce, s'il l'a arraché aux flammes, s'il l'a empêché d'être englouti sous les flots d'une onde courouçée [sic]; enfin, s'il a préservé ses jours de tout autre péril éminent, et que la société récompense cet individu de cet acte de relation volontaire particulière, cette récompense est un acte moral de la société d'état]. 
and his faculties to the highest levels. "Man" - he says - "is a living being, whose instinct is susceptible to the widest development and the greatest perfection".98

Although Dobruska aims to use a scientific procedure, the way he conceives of this procedure is still very rudimentary. As is obvious, given his time, he does not use empirical data collection techniques as we know them today, accustomed as we are to questionnaires on representative samples of the population under investigation.

However, Dobruska uses two other methods to obtain "empirical data" on which to base his knowledge of human beings as social beings. On the one hand, he uses comparison of different societies while, on the other hand, he also provides a historical analysis of certain phenomena, i.e. how they have evolved over time.

The comparison used by Dobruska does not draw contrast between the animal level and the level of men, but between different societies in a given historical period. This allows Dobruska the sociologist to better focus on certain social phenomena and arrive at the formulation of certain laws that, as we have seen, are always based on the principle of cause and effect.

As an example, in the chapter on freedom, Dobruska tries to explain why, in societies that develop in the same natural climate, there can be such varied customs regarding the sexual habits of men and women and such varied drinking customs. In societies where the inhabitants are predominantly Christian, men "limit themselves to the pleasure of a single hymen and drink unscrupulous wine, while in societies where the inhabitants are predominantly Muslim, they abandon themselves to polygamy and refrain from this intoxicating liqueur". 99

Dobruska shows that the cause of these differences in sexual and culinary customs in peoples is not due to climatic factors but to two social-cultural and political factors: the type of legislation and the content of the constitution. ${ }^{100}$

Before the French Revolution, societies, without any distinction between political and religious power, were essentially teleological. The social order was justified by a divine principle.

98 Ibidem, 82: [L'être-homme est un être vivant dont l'instinct est susceptible du développement le plus étendu et de la plus grande perfection].

99 Ibidem, 196: [(. . .) bornant les plaisirs de l'himen à'une seule femme, boit du vin sans scrupule,tandis que l'autre abandonnée à la poligamie la plus voluptueuse, s'abstient de cette liqueur enivrante].

100 Ibidem, 197: [Il n’y a pas sur la terre, une différence entre peuple et peuple; mais bien entre législateur et législateur, entre constitution et constitution]. 
Therefore, the causes that, for Dobruska, distinguish one people from another, are twofold: on the one hand, the "legislators" - in the aforementioned case of Christianity and Islam, they are Christ and Muhammad - and, on the other hand, their "constitutions" - the Gospels and the Koran. The different populations are thus socialized, one might say in today's sociology, according to different systems of religious beliefs, which affect the behavior and habits of people's daily lives.

We can also see in this case how Dobruska comes to the formulation of a law of cause and effect through an inductive method (from the particular to the general) and a comparison between different societies.

Auguste Comte, in the Cours de philosohie positive, which appeared in 18301842, would later theorize about how much such a method could contribute to the scientific analysis of society, to an understanding of human behavior in the social world. As I will show in the final chapter, it is possible to locate a line of development that, in this and other points, leads from Dobruska to Comte.

In Comte, we will arrive at the:

rational comparison between the different coexisting states of human society on the different earth's surfaces, considered above all in populations fully independent of each other. Nothing is more suitable than such a procedure to characterize precisely the different essential phases of human evolution, which, consequently, can be explored simultaneously. ${ }^{101}$

Finally, the last methodological approach which Dobruska often uses to formulate his own "sociological" theories in the form of laws is a historical one. This is the observation of societies which have historically followed one another over time.

As an example, consider the concept of equality. According to Dobruska, equality is to be understood as equality of rights, which is the only way to guarantee the true freedom of each individual. It should not be seen as a fair distribution of economic and social resources among the citizens, which for Dobruska would be against nature.

As a demonstration of his theory, he cites a case taken from ancient Greek history, in which the equitable distribution of resources would have failed its objectives. The example concerns Sparta, under the legislator Lycurgus, to

101 Auguste Comte, Physique sociale. Cours de philosophie positive (leçons 46-60) [18401842] (Paris: Hermann, 1975), 146: [ . . . un rapprochement rationnel des divers états coexistants de la société humaine sur les différentes portions de la surface terrestre, envisagés surtout chez des populations pleinement indépendantes les unes des autres. Rien n'est plus propre qu'un tel procédé à caractériser nettement les diverses phases essentielles de l'évolution humaine, dès lors susceptibles d'être simultanément explorées]. 
whom, according to tradition, we owe legislation that wanted to induce Spartans to austerity and military virtues. In order to achieve his objective, Lycurgus implemented drastic policies aimed at fairly distributing, we would say today, the socio-economic resources among citizens. Amid his interventions - recalls Dobruska - there was the abolition of the use of gold and silver and the introduction of iron coins:

Lycurgus divided the land among his Spartans in equal parts. He destroyed the value of gold and silver, banned Lacedaemonian science and fine arts, wealth and luxury. He limited the clothing and food of the Spartans to the bare minimum. ${ }^{102}$

According to Dobruska, the fair redistribution of economic resources and the abolition of luxury did not produce what Lycurgus hoped for. The policies of strong redistribution of wealth would in fact have restricted the moral capacities of individual citizens linked to mutual support, bringing a consequent inertia of the material and intellectual appetite of individuals.

The historical comparison allows Dobruska both to grasp similar characteristics between past and present, as in the cited case, and to underline the differences between contemporaneity and past ages, which I will discuss below where I go deeper into the theory of the development of the stages of humanity. ${ }^{103}$ In this regard, it is worth recalling the historical approach of Montesquieu, in The Spirit of the Laws of 1748:

When I have been obliged to look back into antiquity, I have endeavoured to assume the spirit of the ancients, lest I should consider those things as alike which are really different, and lest I should miss the difference of those which appear to be like. ${ }^{104}$

\subsection{The Revolutionary Theory}

The first "revolutionary" part of the Philosophie sociale opens with a quote from John Locke (1632-1704): "Blind submission to the feelings of the greatest men

102 Dobruska, Philosophie sociale, 203-204: [Licurgue fit le partage des terres et les divisa entre ses Spartiates par parties égales. Il anéantit la valeur de l'or et de l'argent, il bannît les sciences et les beaux: arts de Lacédémone les richesses et le luxe. Il borna le vêtement et la nourriture des Spartiates au plus étroit nécessaire].

103 See below, 3.10.

104 Montesquieu, Tutte le opere, 896-899: [Quand j'ai été rappellé à l'antiquité, j’ai cherché à en prendre l'esprit, pour ne pas regarder comme semblables des cas réellement différens, et ne pas manquer les différences de ceux qui paroissent semblables], Idem, The complete Works of M. de Montesquieu, Volume the First, (Dublin: W. Watson, 1777), xxxviii. 
has arrested the progress of knowledge more than anything else". ${ }^{105}$ In reality, these words are not taken directly from the work of the English thinker, but from Pierre Coste's Notice to his own French translation of Locke's ${ }^{106}$ Essay on the Human Intellect. In turn, Coste summarizes the autonomy of judgement that Locke himself repeatedly claims, detaching himself from the habit of relying on the auctoritates of the past. ${ }^{107}$ The reference is not accidental, since Locke is an important source of inspiration for Dobruska. And so is, in particular, the Essay, published for the first time in 1690, in which Locke ${ }^{108}$ "intended to see how human reason works, so that men can establish among themselves a form of peaceful and free coexistence, a form of coexistence that [. . . ] makes it possible for everyone to seek his happiness in this world". ${ }^{109}$

If, for Locke, "a desire of Happiness, and an aversion to Misery [. . .] do continue constantly to operate and influence all our Actions”, Dobruska's approach is similar: he examines the philosophical, moral and pragmatic foundations that allow us to build a social order in which human beings can be happy. ${ }^{110}$

After the fall of the absolutist and despotic monarchy of Louis XVI of Bourbon (1754-1793) and the power of the clergy, Dobruska was forced to respond to crucial and urgent philosophical, social, and political questions. On what philosophical basis and on what ethical and moral principles can the French people build a new social order? How is it possible to establish a structure that aims to achieve the happiness of the people and not their oppression? Why is a new society needed and how will it develop? What kind of political regime can guarantee the happiness of citizens? Which legislator is required?

This is precisely the aim of the Philosophie sociale: the construction of a new order, which provides for the establishment of a representative democratic regime. According to Dobruska, civil society within a democratic state can be achieved in three stages.

105 Dobruska, Philosophie sociale, 1: [La soumission aveugle aux sentiments des plus grands hommes, a plus arrêté le progrès des connoissances, qu'aucune autre chose].

106 John Locke, An Essay Concerning Humane Understanding (London: the Basset, 1690 [but 1689]). The French translation by Pierre Coste (1688-1747) was first published in Amsterdam in 1770: Essai philosophique concernant l'entendement humain (the passage quoted by Dobruska is on page 1).

107 See e.g. Locke, An Essay, I. 3. 23.

108 It has to be said that Dobruska always misspells this as "Loke".

109 Introduzione, in John Locke, Saggio sull'intelletto umano, eds., Marian and Nicola Abbagnano (Torino: Utet, 1971), 12.

110 Locke, An Essay, I. 3. 3 (Idem, An Essay Concerning Human Understanding, edited by Peter H. Nidditch, (Oxford: Oxford University Press, 1975), 67. 
In the first stage, it is necessary to deconstruct and break down the old social order, which was the harbinger of so much oppression and unhappiness. Social disorganization is necessary.

In the second stage, it is a question of defining, from a theoretical point of view, the general principles of a Universal Constitution, and I will deal with this in detail later on.

In the third stage, an "explanatory framework" (tableau) will have to be created, i.e. a schematic summary, which will have to be displayed in the national assemblies of the legislative body ${ }^{111}$ and of the popular sections, and will serve as a basis for the promulgation of laws and for their control.

A prerequisite for the whole process is that democracy must be representative and that there must be a clear separation between the religious and state spheres.

This philosophical reflection is revolutionary, since it is inserted in an age of radical changes of the structures and of the social order. It is divided into two interlinked moments of reflection.

The first moment concerns the process of "social disorganization" of the Ancien Régime, while the second refers to the "process of reconstruction of a social order", supported by a critical philosophical reflection, which defines the criteria of a good legislator and new laws for a better social order than the absolutist monarchy, or a body of rules based on a Constitution whose purpose is to make citizens happy.

\subsection{Social Disorganization}

In this paragraph we will dwell on the first process, that of social "disorganization", a concept that would become central in sociological discourse, from the recognized fathers of the discipline to contemporary sociologists, as we will see in the third part of this study.

Dobruska's social-philosophical thought starts from the assumption that, in order to build a new social order, aimed at the happiness of citizens, it is first necessary to destroy the old order.

Désorganisation, désorganiser, désorganisateur - these are words that come back several times under the pen of our author, with each applied to different fields. At the time when Dobruska wrote his Philosophie sociale, désorganisation was a new term, a neologism introduced in the eighties of the eighteenth century. It is interesting to note that the first use of the word was in the description of the

111 Dobruska, Philosophie sociale, 235-236. 
techniques of mesmerism, the hypnotic-manipulative practice used by Franz Anton Mesmer (1734-1815), through which the body balance of the patient is "broken down", or "disorganized", and then reassembled. ${ }^{112}$ The first use of désorganiser, in the historical-political sense, that I was able to find, recurs in a speech by Honoré Gabriel de Riqueti, Count of Mirabeau (1749-1791), printed after his death in Paris in 1791. Here it is used to describe the revolutionary storm, in which reconstruction is necessarily preceded by a process of disorganization:

You have perceived that abuses form a system whose ramifications are intertwined and identified with public existence and that, in order to reconstruct everything, it is necessary to disorganize everything. ${ }^{113}$

As we can see, this is a fleeting mention, which Mirabeau does not elaborate any further. We will find this double movement, of disintegration and reconstruction, developed much more widely, in the Philosophie sociale.

For Dobruska, disorganization is a phenomenon attested by history, which appears in periods of transformation and revolution, thanks to outstanding personalities capable of questioning and changing the order of the past. It begins with the philosophical revolution of Socrates, passes to the revolutionary Christ of the Gospels, until arriving at Immanuel Kant, for whom Dobruska has a deep respect. ${ }^{114}$

The first revolution of sound reason is due to Socrates, who - writes Dobruska - was sentenced to death for having overthrown the philosophical system of the Sophists. Socrates is attributed with the affirmation of ideas not linked to experience, and not yet verified with certainty by science:

Revolutionary Socrates, the first martyr of sound reason, of love for truth, for humanity, was condemned to death for having rejected sophistry, and demonstrated that there are

112 Cf., e.g., Erich J. Biester, "Magnetische Desorganisation und Sonnambulism," Berlinische Monatschrift 9 (1785): 126-160. See also Ralf Klausnitzer, Poesie und Konspiration. Beziehungssinn und Zeichenökonomie von Verschwörungsszenarien in Publizistik, Literatur und Wissenschaft 1750-1850 (Berlin, New York: De Gruyter, 2007), 321-332 ("Magnetische Organisation der Menschheit”- Mesmerismus).

113 Honoré Gabriel de Riqueti Mirabeau, Discours de monsieur Mirabeau l'ainé sur l'éducation nationale (Paris: Lejay, 1791), 1-2: [vous avez senti que les abus formoient un système dont toutes les ramifications s'entrelaçoient et s'identifioient avec l'éxistence publique, et que, pour tout reconstruire, il falloit tout désorganiser].

114 Dobruska, Philosophie sociale, 47: [Socrate révolutionnaire, le premier martyr de la saine raison, de l'amour pour la vérité, pour l'humanité, fut condamné à mort pour avoir renversé la sophistique, et démontré qu'il y a des idées, que l'expérience ne nous donne point, et sur lesquelles nous n'avons point encore de science et de donnée assez certaine, pour nous mettre au-dessus de tout doute. Voilà la première révolution de la saine raison]. 
ideas that experience does not give us at all, and on which we do not yet have a very certain science nor data, to put us above any doubt. This is the first revolution of holy reason. ${ }^{115}$

The second deconstruction is that brought by the revolutionary Christ, which Dobruska defines in these terms:

Christ is the second martyr of sound reason, crucified by Jewish priests and the Roman praetor, as a disorganizer of the astute pagan theocracy and that of Moses, and for having separated heaven from earth, affirming: I have fulfilled the prophecies of Moses, etc., by bringing morality back to good works, and by teaching that one must not only submit to the law, but also pay homage to it. Here is the second revolution of holy reason, the second degree of philosophy. ${ }^{116}$

For almost eighteen centuries, however, the verb of Christ has been overwhelmed by the dogmas of priests - "the scholastic hydra” (l'hydre scolastique) although, writes Dobruska, philosophical and priestly revolutions have not been lacking. Just think of Luther, Zwingli, Melanchthon, Calvin, Huss, Spinoza, Leibniz, Locke and others. It is interesting to note the inclusion, in this list, of heroes of resistance to obscurantism, of promoters of the Reformation, in the company of the always revered, and very unorthodox, Spinoza. Despite the efforts of so many reformers, reason has become "ever more limping [. . .] and the night [of the spirit] ever darker". ${ }^{117}$ It is a pessimistic vision of the early modern age, which finds its redemption only in the last "revolutionary giant". The third revolution of healthy reason is to be found in the thought of the German philosopher Immanuel Kant. The "immortal Kant", as Dobruska calls him, is the great disorganizer of all philosophical systems. But his is a revolution for insiders, understandable only to those who know how to decipher his "metaphysical-technical style”. And so much innovative force of thought would have risked being lost, due to the ignorance of contemporary readers, if the revolution of the French people had not taken care of making it fully accessible:

115 Ibidem.

116 Ibidem, 47-48: [Le Christ révolutionnaire et second martyr de la saine raison, crucifié par les prêtres juifs, et le préteur romain, comme désorganisateur de l'astucieuse théocratie des Payens et de Moyse, et pour avoir séparé le ciel de la terre, en disant: j'ai accompli les prédictions de Moyse, etc. etc., en rappelant la morale à la bienfaisance, en apprenant qu'il ne faut pas seulement se soumettre à la loi, mais qu'il faut aussi lui rendre hommage. Voilà la seconde révolution de la saine raison, le second degré de la philosophie].

117 Ibidem, 48: [(. . ) malgré les diverses révolutions philosophiques et sacerdotales de Luther. Zuingle, Melanchton, Calvin, Huss, Spinosa, Hobbes, Leibnitz, Loke, et autres, la raison toujours plus chancellante, n'en devint que plus malade, les disputes, les égaremens toujours plus fréquens, et la nuit toujours plus sombre]. 
But finally we see appear, as a new revolutionary giant in philosophy, this destroyer of the two pillars of skepticism and dogmatism, this disorganizer of all philosophical systems, the immortal Kant. He can only be read by philosophers, having written in a metaphysical-technical style. Because of the novelty of his ideas, he was forced, so to speak, to compose a new vocabulary, which makes his works even more unintelligible to ordinary readers. But already too advanced in age, and living in Königsberg in Prussia, whose priests and the king are not so clairvoyant as intolerant, his obscure, metaphysical set serves him very well as a talisman against hemlock and the cross. Never has a man written so wisely; never has falsehood been so well unmasked; never has the truth been established in its rights with such assurance; but it has still taken the human spirit four centuries to develop, to feel his excellence, and these lessons seemed to be lost to us; it was reserved for the French nation to make us cross this space, and to make us believe that the most sublime truths, and those which, until recently, were considered the most abstract ones will now be for everyone. ${ }^{118}$

This praise of Kant as a disorganizer did not go unnoticed. A few months after the publication in Paris of the Philosophie sociale, the German philosopher Johann August Eberhard (1739-1809) took up this union between Kant's “disorganizing" philosophy and the political revolution, making it the theme of a polemical essay. As I will demonstrate in more detail in the last chapter of this essay, Dobruska's theory of disorganization was immediately echoed in the intellectual world of the time.

In the Philosophie sociale, disorganization identifies and critically evaluates all the social and political processes both of the society of the past, under the absolutist monarchy of Louis XVI, and of the contemporary one - the one the author is living through - that have led or may lead to great inequalities and social injustices, as well as abuses of power.

118 Ibidem, 48-49: [Mais enfin on voit paroître, comme un nouveau géant révolutionnaire en philosophie, ce destructeur des deux colonnes principales du scepticisme et de la dogmatique, ce désorganisateur de tous systèmes philosophiques, l'immortel Kant. Mais il ne peut être lu que par des philosophes, ayant écrit dans un style métaphisico-technique, pour lequel, en raison de la nouveauté de ses idées, il lui a fallu, pour ainsi dire, composer un nouveau vocabulaire, ce qui rend ses ouvrages d'autant plus inintelligibles au commun des lecteurs. Mais déjà trop avancé en âge, et vivant à Königsberg en Prusse, dont les prêtres et le roi ne sont pas si clairvoyans qu'intolérans; sa parure obscure, métaphysique lui sert très-bien de talisman contre la ciguë et la croix. Jamais homme n'écrivit avec autant de sagacité; jamais la fausseté ne fut aussi bien démasquée; jamais la vérité établie dans ses droits avec une telle assurance; mais il falloit encore à l'esprit humain un développement de quatre siècles, pour en sentir l'excellence, et ses leçons sembloient perdues pour nous; il étoit réservé à la nation françoise, de nous faire franchir cet espace, et de nous faire croire que les vérités les plus sublimes, et celles qui, n'aguères, passoient pour les plus abstraites, seront désormais à la portée de tout le monde]. 
Dobruska reflects critically on everything that did not work in pre-revolutionary society, developing the task that Jean-Jacques Rousseau had already undertaken in his essays on social inequalities (Discourse on the Origin and Foundations of Inequality among Men, 1755), and which was to be continued by subsequent social philosophers, up to the present day. Axel Honneth calls such dysfunctions "the pathologies of the social" or "social pathologies", and means "all erroneous social developments" (soziale Fehlentwicklungen): those processes that deviate from an acceptable ethical-social normative model, of which we will say more later.

What are the developments and processes identified by Moses Dobruska in the pre-revolutionary period, that of the absolutist monarchy, considered harmful to society and to be amended?

The first "explosive mixture" of the absolute monarchy is the division of men into different social classes. Moses Dobruska's reasoning starts from the observation that the monarchy is a form of government "against nature".

Why is it against nature? Because monarchic power is based on a false assumption: the inequality of men, who are divided into different social classes. What is more, only some of them have the right to be citizens, while others are denied that right. This is a serious error that has characterized the absolute monarchy of Louis XVI. Humanity is not divisible: it is a whole. Dobruska writes:

Humanity is certainly an indivisible whole because only man can be found in it. Only tyrants or narrow-minded legislators have been able to divide man into different classes, by establishing various selves in the great self of society. Some (the tyrants) did not want man because they wanted to have slaves, and others (the narrow-minded legislators), not believing that it was possible for man to exercise his rights in society, molded their government on this false opinion, and by a kind of ostracism, they thus banished man from humanity. ${ }^{119}$

The second explosive mixture of the absolutist monarchy is tyranny and lack of attention to the common good. This disease is due to the misallocation of legislative power and its purpose. Since not all individuals are equal before the law, only a few are allowed to reign over the rest of the population and to legislate. In a monarchic regime, it is not the legislative power based on a constitution that legislates, as in a democratic regime, but directly the executive power. The members of the executive carry out the laws exclusively

119 Ibidem, 28-29: [L'humanité est assurément un tout indivisible, car on ne peut y trouver que l'homme. Il n’y a que les tyrans ou les législateurs bornés qui en établissant divers moi dans le grand moi de la société, aient pu diviser l'homme en classes différentes. Les uns (les tyrans) ne vouloient pas l'homme, afin de se faire des esclaves, et les autres, (les législateurs bornés) ne croyant pas qu'il lui fût possible d'exercer ses droits dans la société, moulèrent leur gouvernement sur cette opinion fausse, et par une espèce d'ostracisme, ils bannirent ainsi l'homme de l'humanité]. 
to achieve their own personal ends, essentially following their own whims instead of the common good of society. Dobruska writes: "[. . .] the monarchy, this regime against nature, where force, the executive power, made the law for the execution of its whims, of its licenses". 120

Finally, this leads to great abuses of power and privileges by an oppressive majority that often imposes its will through the law of the strongest, and, in the final analysis, this means a lack of freedom for those who are oppressed by it. This is the third big mistake, which he calls the great "political crime". ${ }^{121}$

Moses Dobruska's social philosophy, however, not only highlights the errors and criticisms of the social order of the absolutist monarchy, but also the social risks of proposals for democratic change which are not based on the Universal Constitution envisaged by him.

Unlike Jean-Jacques Rousseau, Moses Dobruska is convinced that a democracy whose right is not anchored in the Constitution, and which is not rooted in the laws of nature but in the general will of the majority in power, is a serious risk to future society. He wisely states:

We just changed the mode of despotism. After destroying the monarchy [. . .] we put on the throne, in its place, the whims and licenses of the will, of the legislative power: anequally oppressive regime, and one against nature, since it does not reduce the physical [dimension], that is, the force, the execution to slavery, does not reduce the possibility of being able to surrender to license or tyranny. ${ }^{122}$

The Philosophie sociale outlines the social issues (les questions sociales) of both a monarchic regime and a democratic system that is not anchored in the Universal Constitution, which he considers essential.

120 Ibidem, 13: [la monarchie, ce régime contre nature, où la force, la puissance exécutive faisoit la loi pour l'exécution de ses caprices, de ses licences].

121 For a sociological and diachronic evaluation of power processes and institutions see KarlSiegbert Rehberg, "Institutionelle Machtprozesse im historischen Vergleich. Einleitende Bemerkungen”, in Dimensionen institutioneller Macht. Fallstudien von der Antike bis zur Gegenwart, eds., Gert Melville and Karl-Siegbert Rehberg (Köln, Weimar, Wien: Böhlau, 2012), 1-16; Karl-Siegbert Rehberg, "Institutionelle Analyse und Historische Komparatistik," ibidem, 417443; Symbolische Ordnungen. Beiträge zu einer soziologischen Theorie der Institutionen, eds. Karl-Siegbert Rehberg and Hans Vorländer (Baden-Baden: Nomos, 2014).

122 Ibidem: [Nous n'avons donc changé que le mode du despotisme, et en détruisant la monarchie, ce régime contre nature, où la force, la puissance exécutive faisoit la loi pour l'exécution de ses caprices, de ses licences, nous plaçâmes donc sur le trône les caprices et les licences de la volonté, de la puissance législative: régime également oppressif, et contre nature, puisqu'il ne réduit le physique, c'est-à-dire, la force, l'exécution à l'esclavage, qu'afin de pouvoir s’abandonner plus aisément lui-même à la licence ou à la tyrannie]. 
As we have seen in the previous paragraph, Dobruska, in addition to pointing out everything that is wrong with social reality, also outlines a political criticism. It is a criticism that addresses a specific regime, the monarchist regime, and its protagonists, but it is also a criticism that invites the recipients of his Philosophie to transform social reality. ${ }^{123}$

Like the natural scientists, after the "diagnosis" he also tries to identify the "causes" of the serious errors of the previous political regime, which led to the rebellion of the population and what he calls the "social disorganization".

As we have already mentioned, there are many causes. These reside primarily in the distinction between men and citizens and all those who, by definition, do not enjoy the rights of citizenship. Other causes of disorganization are to be identified in the stratification into social classes and in the possibility, on the part of the executive power, of legislature taking into account only personal interests, or "whims", as Dobruska calls them.

Dobruska praises Jean-Jacques Rousseau as one of the first to encourage men to free themselves from the yoke of submission. Rousseau is, in the Philosophie sociale, the father of the French Revolution and the benefactor of humanity. ${ }^{124}$ The dissemination of his writings had the merit of inspiring the French people and thus initiating the revolutionary process in France. It is primarily thanks to him that the French have become aware of the lack of freedom and the oppressive daily life imposed on them by the absolutist monarchy, and have been able to free themselves from the yoke of tyranny.

Suffice it to recall, in this regard, the famous opening of the first chapter of The Social Contract (1762):

Man is born free; and everywhere he is in chains. One thinks himself the master of others, and still remains a greater slave than they. How did this change come about? I do not know. What can make it legitimate? That question I think I can answer.

If I took into account only force, and the effects derived from it, I should say: "As long as a people is compelled to obey, and obeys, it does well; as soon as it can shake off the yoke, and shakes it off, it does still better" [. . .] To renounce liberty is to renounce being a man, to surrender the rights of humanity and even its duties. For him who renounces everything no indemnity is possible. Such a renunciation is incompatible with man's nature; to remove all liberty from his will is to remove all morality from his acts. ${ }^{125}$

123 Fischbach, Manifeste pour une philosophie sociale, 38.

124 Dobruska, Philosophie sociale, 19.

125 Jean-Jacques Rousseau, Du contrat social. Ou, Principes du droit politique (Amsterdam: Chez Marc-Michel Rey, 1762), I. 1. 3, I. 4. 16: [L'homme est né libre, et par-tout il est dans les fers. Tel se croit le maître des autres, qui ne laisse pas d'être plus esclave qu'eux. Comment ce changement s'est-il fait ? Je l'ignore. Qu'est-ce qui peut le rendre légitime ? Je crois pouvoir 
Dobruska completely agrees with Rousseau. Lack of freedom must be combated, independence must be regained at all costs, oppression must be resisted, and tyranny must be broken down. ${ }^{126}$ Lack of freedom and oppression are the negative traits that have marked the social order of the absolutist monarchy and that must be banned from the new society.

\subsection{Critical Diagnosis and Conditions for Overcoming Social Disorganization}

If Dobruska's social philosophy is against the pre-revolutionary regime, it also presupposes some hypotheses on how it is possible to create a society that makes citizens happy.

A first hypothesis refers to the elimination of the distinction between citizens and non-citizens, between politicians and civilians, which were introduced by the monarchy. ${ }^{127}$ For Moses Dobruska all men are social beings who live in close association, are equal before the law, and must be able to participate as citizens in democratic society.

A second hypothesis refers to what is to be understood by man, that is, in the language of the Philosophie sociale, by the être-homme. For Dobruska, man "is a living being whose instinct is susceptible to the greatest development and perfection". 128

The condition in which human being can develop his own power and reach the highest level of perfection is freedom. As we know, for Dobruska, freedom means equal rights. This is the third condition for the realization of a just and happy society.

résoudre cette question [. . . . Si je ne considérois que la force, et l'effet qui en dérive, je dirois ; tant qu'un Peuple est contraint d'obéir et qu'il obéït, il fait bien ; sitôt qu'il peut secouer le joug et qu'il le secoüe, il fait encore mieux [. . . ] Renoncer à sa liberté c'est renoncer à sa qualité d'homme, aux droits de l'humanité, même à ses devoirs. Il n'y a nul dédommagement possible pour quiconque renonce à tout. Une telle renonciation est incompatible avec la nature de l'homme, et c'est ôter toute moralité à ses actions que d'ôter toute liberté à sa volonté], Idem, The Social Contract, and Discourses, introduction by G. D. H. Cole, (London: J.M. Dent \& Sons, Ltd, 1910), 10.

126 Philosophie sociale, 1.

127 Ibidem, 82: [L'être-homme est-un être vivant dont l'instinct est suscetible du développement le plus étenduet de la plus grande perfection].

128 Loc. cit. 
It follows - and this is the fourth condition - that freedom is guaranteed only by the application of the Universal Constitution. As we shall see later, the Universal Constitution drawn up by our author contains all of the ethical and social principles or rules, the purpose of which is to reorganize society in a democratic way, while guaranteeing the happiness of citizens.

Finally, one last important condition, which prevents the occurrence of what Moses Dobruska calls the "monstrous mixtures" (mélanges monstrueux), is the separation between religious power and political power - a separation that was not practised in the regime of the absolute monarchy of Louis XVI.

The justification for monarchic power from antiquity to the French Revolution has always been based on the divine descent of the monarchs themselves. In this regard, Dobruska notes in the first part of his work:

In ancient times, the whole land was subject to the sovereignty of the gods. The sovereigns were their representatives. All forms of government were theocratic. Kings, heroes and all those who commanded a people - whatever their name - were so identified with the divinity of their nation that attacking one meant attacking the other. History and the Bible provide us with constant proof of this truth. I could never conceive how men, even the most enlightened of our century, could consider such a monstrous mixture, this disastrous identification, as a necessary fact of the organization of primitive nations, as an advantage and a perfection of the same. I have always thought, however, that legislators who did not have a primitive people to establish, but who had to regulate a government of a people already dominated by superstition, saw this vicious union as a tool for them and as a necessary evil. ${ }^{129}$

It can be seen from all of this that the Philosophie sociale has a strongly evaluative and normative dimension. This is a characteristic of normativity, which will shape all future social philosophy. ${ }^{130}$

129 Ibidem, 40: [Toute la terre étoit anciennement soumise à la souveraineté des Dieux. Les rois étoient leurs représentans. Toutes les formes du gouvernement étoient théocratiques. Les rois, les héros, et tous ceux qui commandoient à un peuple; quelle qu'ait été leur dénomination étoient tellement identifiés avec la divinité de cette nation, qu'attaquer l'une, c'étoit aussi attaquer l'autre. L'histoire et la bible nous offrent la preuve continuelle de cette vérité. Je n'ai jamais pu concevoir comment les hommes, même les plus éclairés de notre siècle, avoient pu considérer ce mélange monstreux, cette identification funeste, comme un effet nécessaire de l'organisation des nations primitives; et par suite, comme un avantage et une perfection de cette constitution; mais j'ai toujours pensé, que les législateurs qui n'avoient point eu un peuple primitif à instituer, mais à réguler le gouvernement d'un peuple déjà dominé par la superstition, j'ai toujours pensé, dis-je, que ces législateurs avoient regardé cette réunion vicieuse, comme un moyen pour eux, et comme un mal nécessaire]. See also below, 7. 3. 3.

130 See Jaeggi, Celikates, Sozialphilosophie, 8; Fischbach, Manifeste pour une philosophie sociale, passim. 


\subsection{Theory of the Historical Development of Social Organizations}

As we shall see in more detail in the final chapter, Dobruska is a forerunner of the law of the three stages of humanity, elaborated later, in the nineteenth century, by Auguste Comte.

According to the thesis developed in the first part of the Philosophie sociale, humanity has built different social organizations, each one of them belonging to a specific epoch, and characterized by peculiar sources of legitimacy of power.

In the first phase of the development of humanity, what we might call the "theocratic" phase, the source of legitimacy of societies was the gods. The first source of legitimacy for political regimes, from antiquity to the absolute monarchy of the pre-revolutionary era, was therefore of a religious nature. The leaders of the ruling classes identified with the gods. This correlation, which turned into a disastrous identification of temporal power and religious power, is, according to Dobruska, a "monstrous mixture” (mélange monstreux), “[. . .] a necessary effect of the social organization of primitive nations". ${ }^{131}$ In primitive social organizations, the legislator couldn't educate the people, subject as they were to superstition, so this vicious union between secular and religious power was a necessary evil.

This first phase of social organizations was followed by a second phase, although Dobruska does not provide historical details. In this phase, social organizations were justified and sustained on the basis of a constitution and legislation, which had their roots in a metaphysical system of thought, that is, one that looks beyond the sensible world, in search of the ultimate goals of man's existence, and the deeper meaning of his life.

In the second part of the Philosophie sociale, we learn how a social organization, whose normative system is based on a metaphysical system that transcends empirical reality, can only cause "trouble”. It won't be able to make its members happy.

Dobruska emphatically states:

Woe to them [the people] if they seek another basis for his own judgment! Because then they throw themselves into the circle from which they have struggled to escape [the theocratic one] [. . . ] It is in this way that trouble persecutes the metaphysicist at every step, who dives into the syllogisms and their painful consequences, copies and forms his

131 Dobruska, Philosophie sociale, 40: [ce mélange monstreux [. . .] un effet nécessaire de l'organisation des nations primitives]. 
system, following everything but nature. It is for this reason that in legislation the indepth debate became painful and dictated by the word metaphysics. ${ }^{132}$

In order to achieve the happiness of citizens, the new social organization will have to distinguish itself from theocratic and metaphysical social organizations.

We have thus reached the third and final historical phase, in which another ideal type of social organization is realized. The source of legitimacy of power is no longer based on theology, nor on metaphysics, but on the "laws of nature".

This social organization, which was born in the aftermath of the French Revolution, is the one that Dobruska intends to achieve with his work. It is a democratic society, whose order is based on the Constitution. The inspiring principle is no longer metaphysics but physis, nature, with its laws.

Dobruska writes:

It is true that when the legislation will have found the solid foundations of nature, and will apply physics in a perfect way, we will no longer need metaphysics, in this sense we can say with Bacon post veram inventam physicam nulla metaphysica erit. That is to say that once we have known nature, we should no longer seek beyond it. ${ }^{133}$

As we shall see below, with regard to the essence and form of the Universal Constitution, Dobruska is convinced that constitutional principles must be sought in the laws of nature and no longer in metaphysics or even in religion.

Once the Constitution has been drawn up, with the principles for achieving a democratic society in which citizens are happy, it will be sufficient for legislative assemblies to meticulously apply the principles set out in it.

The similarity with the thought of Auguste Comte is immediately apparent. As sociologist Lewis Coser recalls in his book on the Masters of Sociological Thought, Comte argues that:

132 Ibidem, 54-55: [Malheur à lui, s'il [le peuple] cherche une autre bâse à son jugement! car alors il se jette dans le cercle dont il avait eu tant de peine de à sortir [celui théocratique] [. . .]. C'est ainsi que le malheur poursuit à chaque pas le métaphysicien qui, plongé dans des sillogismes et des conséquences pénibles, copie et forme son systême, suivant tout, excepté suivant la nature. C'est par cette raison que dans les législations toute discussion approfondie devenoit odieuse et proscrite par le mot métaphysique].

133 Ibidem, 55: [Il est vrai que lorsque la législation aura trouvé les bases solides de la nature, en fait l'application parfaite de la physique, nous n'aurons plus besoin de la métaphysique, dans ce sens, nous pourrions dire avec Bacon, post veram inventam physicam nulla metaphysica erit. C'est-à-dire, quand nous connoîtrons une fois la nature, nous n'aurons plus à chercher au-delà d'elle]. See also below, 7. 3. 3. 
In order for man to be able to transform his nonhuman environment to his advantage, he must know the laws that govern the natural world, "For it is only by knowing the laws of phenomena, and thus being able to foresee them, that we can . . . set them to modify one another for our advantage ... Whenever we effect anything great it is through a knowledge of natural laws . . . From science comes Prevision; from Prevision comes Action ( $\mathrm{Sa}$ voir pour prévoir et prévoir pour pouvoir). In a like manner, social action beneficial to mankind will become possible once the laws of motion of human evolution are established, and the basis for social order and civic concord is identified". ${ }^{134}$

Comte also affirms the need to know the world of nature in order to understand the laws that govern social life. It is only through this knowledge that people can transform the environment in which they live.

The analogy between Dobruska's anticipatory thought and Comte's later one certainly doesn't stop here. As we have already mentioned, and we will illustrate later, Comte elaborates a theory of the development of humanity that goes from a theological stage, to a metaphysical one, up to the positive one, of science. The roots of these stages are to be found in the theory of social organizations, formulated in the Philosophie sociale.

\subsection{Criticism of Rousseau}

Rousseau, tutelary deity of the French Revolution, is exalted in the Philosophie sociale in truly flattering terms: "sacred flame, torch of truth that has enlightened the people and that has burned a multitude of ancient and vexatious laws". ${ }^{135}$

However, these are praises that must not be overestimated. Beyond the appreciation for the figure of the thinker and innovator, Dobruska expresses himself very sharply against the Social Contract of Rousseau, considering it unsuitable to sustain the construction of the future French democratic society. On the contrary, Rousseau's thought would actually only lead to social disorganization and perpetual revolution.

According to Dobruska, it is essential that the French people have a solid body of law, based on a constitution. This body of work is necessary if a new democratic society is to be built. According to our author, a good constitution

134 Lewis A. Coser, Masters of Sociological Thought. Ideas in historical and social context, $2^{\text {nd }}$ ed. (San Diego: Hartcourt Publishers, 1977) (I ed. 1971), 4.

135 Dobruska, Philosophie sociale, 1: [Rousseau fut cette flamme sacrée, ce flambeau de la vérité, qui, en éclairant le peuple, consuma le recueil de ses loix antiques et vexatoires]. 
supports the most rigorous equality, just as we find it in nature, no privileges, no preferences. Equal freedom for all; because it is the natural property, and an indispensable need for happiness for everyone. ${ }^{136}$

In the very first page of his Philosophie sociale, Dobruska therefore states with emphasis: "We must make new [laws]. We have overthrown, dismissed: let us build, constitute! This is the cry of all the French people and of the whole world, who await us."137

Dobruska has five basic critical arguments against Rousseau: the choice of political regimes based on the size of a State and the number of its inhabitants; the lack of a hierarchy of sources of law; the conception of legislative and executive power of a representative democracy; the concept of morality as a will; the lack of a separation between Church and State.

The first criticism of Rousseau refers to the choice of different political regimes, based on the size of a State and the number of its inhabitants. Dobruska criticizes Rousseau's thesis that not all types of political regimes are suitable for different populations and different States. It follows from this thesis that, for larger countries with a higher population density, monarchic regimes are more suitable, for the medium-sized ones aristocracy is more suitable, while the smaller countries with a lower population density are more suitable for democratic regimes. In the eighth chapter of the third book of the Social Contract, entitled Every form of government is not suitable for every country, Rousseau observes:

It follows that, the more the distance between people and government increases, the more burdensome tribute becomes: thus, in a democracy, the people bears the least charge; in an aristocracy, a greater charge; and, in monarchy, the weight becomes heaviest. Monarchy therefore suits only wealthy nations; aristocracy, States of middling size and wealth; and democracy, States that are small and poor. ${ }^{138}$

136 Ibidem, 43: [En partant de là, (d'une bonne constitution,) nous trouverons généralement et en somme la plus rigoureuse égalité, telle qu'elle est dans la nature, nul privilège, nulle préférence. Liberté égale pour tous; parce qu'elle est la propriété naturelle, et un besoin indispensable au bonheur d'un chacun].

137 Ibidem, 1: [Mais il faut en faire de nouvelles. [. . .] Nous avons renversé, destitué; édifions, constituons: voilà le cri du Peuple François et du monde entier, qui nous attend].

138 Rousseau, Du contrat social III. 8: [ . . . the further the distance from the people to the Government increases, the more expensive the tributes become; thus in Democracy the people are the least charged, in the Aristocracy they are more so, in the Monarchy they carry the greatest weight. The Monarchy is therefore only suitable for wealthy nations, the Aristocracy for states that are mediocre in wealth and size, Democracy for small and poor states] (Idem, The Social Contract, 69). 


\title{
To this thesis, Dobruska responds with emphasis:
}

Unhappy humanity! The largest part of humanity is condemned to endless slavery. After the most vigorous struggles against tyranny, does it only have the sad prospect of a new slavery? And you, above all, the French people! What about your great efforts, your great sacrifices that you have made to eradicate tyranny? And your neighbors, who were waiting for your liberating weapons, will have to lower their heads more than ever, since you yourself, after your countless triumphs, will see the sun darken again because of the corrupt spirit of despotism. No, it will be otherwise. The revolutionary genius, your benefactor J.-J. [Rousseau] was wrong. And to convince you, let us examine and ask ourselves: What is a small-, great-, and medium-sized people? ${ }^{139}$

\section{Against Rousseau's thesis that the political regime best suited to a people is re- lated to the size of the territory and the size of the population, Dobruska writes:}

\begin{abstract}
A small State is a society made up of a small number of inhabitants. A large people is a grouping of many individuals and an average people is a society made up of more people than a small society but fewer than a large society. We will discuss in the following the influence of different climates and the nuances that customs can provoke on the wide range of humanity. Here we limit ourselves to emphasizing that man always remains a man, regardless of whether he is united with a few, many, or an intermediate number of individuals. The tree does not change its essence whether it is planted in a large forest, in a smaller forest or almost isolated from other trees. Let's add another truth: a large forest is more resistant to the shock of the winds than a tree that is found only in the plain or in a not very dense forest. Likewise, a large population has more resources for the preservation of its own self (son moi) than a weaker population, as it can multiply and renew its efforts without losing its energy. The one who claims to see the whole of humanity in a different way from the collection of equal human beings multiplied equally and not differently increased, is similar to the one who, in observing a forest, sees everything but the tree. ${ }^{140}$
\end{abstract}

139 Dobruska, Philosophie sociale, 25: [Malheureuse humanité! ainsi donc tes portions les plus grandes sont condamnées à un esclavage sans fin, où après les luttes les plus vigoureuses contre la tyrannie, elles n'auront donc que la triste perspective d'un nouvel esclavage? et toi sur-tout Peuple françois! ils auront donc été vains tes efforts généreux, ils seront donc perdus tous les sacrifices que tu as faits pour l'extirpation de la tyrannie? Tes voisins qui attendoient tes armes libératrices, n'auront donc qu'à courber plus que jamais leur tête, puisque toi-même après des triomphes sans nombre, tu dois voir ton sol flétri de nouveau, par l'haleine impure du despotisme. Non: il en sera autrement. Ton génie révolutionnaire, ton bienfaiteur J.-J. s'est trompé en en parlant ainsi, et pour nous en convaincre, examinons et demandons: Qu'est-ce qu'un peuple petit, un grand peuple, et un peuple médiocre?].

140 Ibidem, 25-26: [Un petit Etat est une société composée d'un petit nombre d'hommes; un grand peuple est le rassemblement de beaucoup d'hommes; et un peuple médiocre, est une société plus nombreuse que la première, et moindre que la seconde. Nous parlerons dans la suite de la diversité des climats, des nuances que les mœurs ou d'autres accidens peuvent jetter sur le grand tableau, l'humanité. Nous nous bornerons ici à dire, que l'homme est toujours homme, soit qu'il se trouve rassemblé en petite, en grande, ou en moyenne quantité. L'arbre 
It is clear that Dobruska understands very well how men act and behave in their daily practices in very different ways, depending on the social and cultural context in which they are "socialized". However, it is also clear to him how, while belonging to different societies, all men share the same essence. As a result, a democratic regime is suitable for any nation, whether large or small, poor or rich. As such, monarchic and aristocratic regimes must be rejected because they are "too contrary to freedom and equality". ${ }^{41}$

The second criticism of the political philosophy of the Social Contract of J.-J. Rousseau focuses on the lack, in the thought of the Genevan, of a hierarchy of the sources of law, which hinders the promulgation of laws. As we shall see below, Dobruska's social philosophy very clearly indicates the need for a hierarchy of regulatory sources.

While it is true that Rousseau outlines the principles for the achievement of a good state and good governance which, as we know, must support the preservation and prosperity of its members, ${ }^{142}$ he does not make them binding. Although these principles are the foundation of the laws, they are not anchored by a Constitution. They risk being baseless. In this regard Dobruska cites a significant passage from the twelfth chapter of the second book of the Social Contract of Rousseau:

The laws which regulate this relation bear the name of political laws, and are also called fundamental laws, not without reason if they are wise. For, if there is, in each State, only one good system, the people that is in possession of it should hold fast to this; but if the established order is bad, why should laws that prevent men from good be regarded as fundamental? Besides, in any case, a people is always in a position to change its laws, how ever good; for, if it chooses to do itself harm, who can have a right to stop it? ${ }^{143}$

ne change point dans son essence, soit qu'il se trouve dans une vaste forêt, qu'il soit planté dans un bois moins étendu, ou presque isolément. Mais nous dirons avec vérité, qu'une grande forêt présente au choc des vents, une résistance plus forte que l'arbre qui se trouve seul dans la plaine, où dans un bois clair semé. De même, un grand peuple a-t-il plus de ressources pour la conservation de son moi, qu'un peuple foible, en ce qu'il peut multiplier à la fois et renouvelle ses efforts, sans qu'ils perdent pour cela de leur énergie; et celui qui voudrait regarder le grand tout de l'humanité autrement, que comme le rassemblement du même être multiplié d'une manière égale, et non pas différemment augmenté, ressembleroit à celui qui, observant une forêt, verrait tout excepté l'arbre].

141 Ibidem, 22.

142 Rousseau, Du contrat social, III. IX (Idem, The Social Contract, 73).

143 Ibidem, II. XII: [Les loix qui règlent ce rapport partent le nom de loix politiques, et s'appellent aussi loix fondamentales, non sans quelque raison si ces loix sont sages. Car s'il n'y a dans chaque Etat qu'une bonne manière de l'ordonner, le peuple qui l'a trouvée doit s'y tenir: mais si l'ordre établi est mauvais, pourquoi prendroit-on pour fondamentales des loix qui l'empêchent d'être bon? D'ailleurs, en tout état de cause, un peuple est toujours le maitre de 
For Dobruska, it is in no way acceptable for a nation to be able to change its laws and replace them with a body of legislation that aims at the evil and destruction of the people themselves. It is for this reason that he intends to draw up a Universal Constitution, containing, as its first principle, the preservation and happiness of citizens. The remaining laws must descend hierarchically from this fundamental principle. If this binding hierarchy, which protects the people from self-destruction, is lacking, a philosophical system cannot serve as a model for building a new social order. In fact, it would be an unstable philosophical system, a harbinger of social disorganization instead of organization. Dobruska says:

But of course, I will demonstrate more widely in the following that his system [i.e. Rousseau's], being disorganizing and perpetually revolutionary, cannot serve as a basis for the Constitution, from which must result the laws that guarantee the duration of freedom. Without freedom there can be no public happiness. ${ }^{144}$

The third criticism of Rousseau's philosophical and political thought is closely linked to the second one. It focuses on the conception of legislative and executive power in a representative democracy.

Rousseau speaks of these two powers in the third book of his The Social Contract, dedicated to the different forms of government (democracy, aristocracy and monarchy):

Every free action is produced by the concurrence of two causes; one moral, i.e. the will which determines the act; the other physical, i.e. the power which executes it. When I walk towards an object, it is necessary first that I should will to go there, and, in the second place, that my feet should carry me. If a paralytic wills to run and an active man wills not to, they will both stay where they are. The body politic has the same motive powers; here too force and will are distinguished, will under the name of legislative power and force under that of executive power. ${ }^{145}$

changer ses loix, mêmes les meilleures; car s'il lui plait de se faire mal à lui-même, qui est-ce qui a droit de l'en empêcher?]. (Rousseau, The Social Contract, 47).

144 Dobruska, Philosophie sociale, 1-2: [Mais certes, et je le démontrerai plus amplement dans la suite, son système n'étant que désorganisateur et perpétuellement révolutionnaire, ne peut plus servir de base à une constitution, d'où doivent découler des loix, qui nous garantissent la durée de la liberté, sans laquelle il ne saurait y avoir de bonheur public].

145 Rousseau, Du contrat social, III. 1. 122-123: [Toute action libre a deux causes qui concourent à la produire, l'une morale, savoir la volonté qui détermine l'acte, l'autre physique, savoir la puissance qui l'exécute. Quand je marche vers un objet, il faut premièrement que j'y veuille aller ; en second lieu, que mes pieds m'y portent. Qu'un paralytique veuille courir, qu'un homme agile ne le veuille pas, tous deux resteront en place. Le corps politique a les mêmes mobiles ; on y distingue de même la force et la volonté ; Celle-ci sous le nom de puissance 
In other words, for Rousseau, the political body must be understood as a physical body. Legislative power corresponds to will, understood as morality, while executive power is force.

For Dobruska, the legislative power has the task of enacting laws, which are expressions of the moral faculties of the legislator. However, these laws and this is a central point of his entire social philosophy - must be based on law, which in turn is based on the ultimate principle and on the seventy constitutional principles. Or rather, laws must be subject to constitutional principles, which are based on reason and observation of nature.

The executive power, completely subordinate to the legislative one, must merely obey and execute. It has no deliberative power, no force of its own, as Rousseau suggests.

Legislative power should therefore be understood as a moral legislative power.

Dobruska says:

. . . about the comparison, which J.J. Rousseau proposes to us, I will say: that it is basically true. But I will also say that, although Rousseau did not confuse the mechanic with the machine, he seems to assume that the mechanic is a dual being. According to his system, it is mistakenly divided into an author of larger and important wheels and another of smaller and less important wheels. Actually, it's still the same being. He is always the artist who made the same machine whether it has big wheels or small ones. ${ }^{146}$

The fourth criticism of the Social Contract is directed against the way of conceiving the moral faculty of the legislative power. If for Rousseau the will represents the only moral instance attributed to the legislative power, for Dobruska the moral instances, of which we will say more later, are always two: sentiment and reason. ${ }^{147}$

The fifth and final criticism concerns the lack of separation between religion and politics.

Dobruska criticizes the thesis of the seventh chapter of the second book of the Social Contract, in which Rousseau states that, since nations existed, there

législative, l'autre sous le nom de puissance exécutive] (Idem, The Social Contract, 49). This passage is quoted in Philosophie sociale, 5-6.

146 Dobruska, Philosophie sociale, 7: [ . . . de la comparaison, que J.J. Rousseau nous propose, je dirai: qu'au fond elle est véritable; mais je dirai aussi que si Rousseau n'a pas tout-àfait confondu le mécanicien avec la machine, il semble pourtant qu'il regard le mécanicien comme un être double, qui, d'après son système, est faussement divisé en auteur des roues plus grandes et plus importantes de la machine, et en auteur des roues plus petites et moins importantes, mais qui en effet est toujours un seul et même être, c'est-à-dire, toujours l'artiste qui a fabriqué la machine elle-même, soit qu'il en fasse les grandes ou petites roues].

147 Ibidem, 19. 
has always been an instrumental link between politics and religion. This is the text by Rousseau:

The Judaic law, which still subsists, and that of the child of Ishmael, which, for ten centuries, has ruled half the world, still proclaim the great men who laid them down; and, while the pride of philosophy or the blind spirit of faction sees in them no more than lucky impostures, the true political theorist admires, in the institutions they set up, the great and powerful genius which presides over things made to endure. ${ }^{148}$

From all this, Rousseau stresses, we must not conclude with the English theologian William Warburton (1698-1779) that politics and religion have a common object. In the origin of nations, one serves as an instrument to the other. ${ }^{149}$

According to Dobruska, for the construction of a democratic society, there must be a separation between Church (conceived as different from the religious thought of Christ) and politics. In fact, in the hands of impostors, religion can only be used for personal purposes and can be harmful to young people. ${ }^{150}$

Dobruska is convinced that, despite its merits, the Social Contract does not offer a convincing guide to a solid foundation on which to reconstruct a democratic society. For this reason, after having offered the criticism that we have summarized, the Philosophie sociale discusses what legal, political and philosophical basess can be used to build a new social order, a new society able to overcome the "social pathologies" of the Ancien Régime - from tyranny to lack of freedom and equality. According to Dobruska, there are three cornerstones of a new democratic order. The first basis is legal, and this provides for a good Constitution, which justifies the established order. In the first part of the Philosophie sociale, which has moreof a philosophical and revolutionary intonation, we read:

Let's start from there (from a good constitution). We will generally and briefly find the most rigorous equality, as in nature. No privileges, no preferences. The same freedom for everyone, since this is the natural property and an indispensable need for the happiness of each individual. ${ }^{151}$

148 Rousseau, Du contrat social, II. 7. 91: [La loi judaïque, toujours subsistante, celle de l'enfant d'Ismaël, qui depuis dix siècles régit la moitié du monde, annoncent encore aujourd'hui les grands hommes qui les ont dictées; et tandis que l'orgueilleuse philosophie ou l'aveugle esprit de parti ne voit en eux que d'heureux imposteurs, le vrai politique admire dans leurs institutions ce grand et puissant génie qui préside aux établissements durable] (Idem, The Social Contract, 38).

149 Loc. cit.

150 Dobruska, Philosophie sociale, 39.

151 Ibidem, 43: [En partant de là, (d'une bonne constitution) nous trouverons généralement et en somme la plus rigoureuse égalité, telle qu'elle est dans la nature, nul privilège, nulle préférence. Liberté égale pour tous; parce qu'elle est la propriété naturelle, et un besoin indispensable au bonheur d'un chacun]. 
From this first strand follows logically the second one. If a new democratic society is to be achieved, one that is rooted in the Universal Constitution, the principle that justified previous social orders, namely the pernicious identification of the gods and sovereigns, who represented the divinity, must be abolished. ${ }^{152}$

Therefore, Dobruska invites both the wise men of every nation (les sages de la terre), who desire the happiness of mankind, and the French people, to move from a traditional legitimacy of the social order, as Max Weber would express it, based on divinity, to a principle of legal-rational legitimacy, based on his Universal Constitution, of which we will go into more detail shortly.

The last cornerstone of Dobruska's social philosophy refers to the ultimate source of the principles of the Universal Constitution. Such a source is to be found in thinkers and in philosophical and religious traditions in which love for the truth is expressed. For our author, there are three emblematic figures: revolutionaries who have marked the development of "healthy reason".

He begins with Socrates, and then passes to the revolutionary Christ of the Gospels, until he reaches Immanuel Kant. ${ }^{153}$

The first revolution of sound reason was brought about by Socrates' philosophy, to which goes the merit of having overthrown the philosophical system of the Sophists. Socrates encourages us to search for the truth, to reach the knowledge that springs from the theoretical reflection of thought, rather than from that of the senses.

The second revolution is that of Christ, whom Dobruska considers the second martyr of sound reason, crucified by Jewish priests and Roman praetors. ${ }^{154}$ He is the great disorganizer of the astute pagan theocracy and of the theocracy of Moses, and has had the merit of separating heaven from earth - the transcendent questions, linked to faith and spirit, from the worldly ones. He urged the believer to submit to his law and pay respect to it. The verb of Christ, however, has been sunk by the dogmas of priests for almost eighteen centuries - as we read in the Philosophie sociale - although there have been several revolutions in the ecclesiastical sphere. Just think of Luther, Zwingli, Melanchthon,

152 Ibidem, 42.

153 Ibidem, 47.

154 Ibidem, 48: [Le Christ révolutionnaire et second martyr de la saine raison, crucifié par les prêtres juifs, et le préteur romain, comme désorganisateur de l'astucieuse théocratie des Payens et de Moyse, et pour avoir séparé le ciel de la terre, en disant: j'ai accompli les prédictions de Moyse, etc. etc., en rappelant la morale à la bienfaisance, en apprenant qu'il ne faut pas seulement se soumettre à la loi, mais qu'il faut aussi lui rendre hommage. Voilà la seconde révolution de la saine raison, le second degré de la philosophie]. 
Calvin, Huss, Spinoza, Leibniz, Locke and others. During all these centuries, reason has begun more and more to stagger, its losses become more and more frequent, and the night more and more deep. ${ }^{155}$

The third revolution of healthy reason is to be found in the thought of the German philosopher Immanuel Kant. Kant was the great disorganizer of all philosophical systems. It is due to the immortal Kant, as Dobruska calls him, if humanity has overcame the second stage and has been able to embrace the third stage of its development. We will see later how this definition of Kant as a revolutionary and “disorganizer” of philosophical thought had immediate echos in the German intellectual world, through the writing of Johann August Eberhard. After having placed himself under the strong and authoritative sign of Kantian work, Dobruska makes a forecast of the future full of pathos:

Religion of the Truth of Principles! I already see the nameless sages preparing their hearts to receive your worship. Come, come, after so many idolatries and idols, so that finally humanity can rejoice in your divinity! ${ }^{156}$

\subsection{Essence and Form of the Universal Constitution}

In the second section of the Philosophie sociale the Universal Constitution is outlined, divided into two fundamental parts (Fig. 2).

The first part of the Constitution contains the exposition of the ultimate principle (the principle of self-preservation) and of the seventy principles that follow from it and that govern society. This part is mandatory and cannot in any way be called into question by members of society. The second part of the Constitution, which is subordinate to the first, represents the application of the principles themselves. The latter, in fact, when put into practice, give rise to

155 Loc. cit.: [Mais l'hydre scolastique dont toutes les têtes n'avoient pu être abattues, reparaissant bientôt, infecta la saine et naturelle doctrine du Christ, en la couvrant d'un amas confus et informe de dogmes sacerdotaux, de commentaires et de nouveaux systêmes philosophiques; fléau du genre humain, pendant presque dix-huit siècles, malgré les diverses révolutions philosophiques et sacerdotales de Luther, Zuingle, Melanchton, Calvin, Huss, Spinosa, Hobbes, Leibnitz, Loke, et autres,la raison toujours plus chancellante, n'en devint que plus malade, les disputes, les égaremens toujours plus fréquens, et la nuit toujours plus sombre].

156 Ibidem, 50: [Religion de la vérité des principes! je vois déjà des savans sans nombre préparer tous les cœurs à recevoir ton culte. Viens, ô viens, et qu'après tant d'idolâtries et d'idoles, qui t’ont occupée, l'humanité jouisse une fois de ta divinité!]. 
the political institutions and the entire body of legislation of a democratic state. ${ }^{157}$ The implementation of the second part of the Constitution is the responsibility of the general assemblies and is not dealt with by Dobruska in his work.

The basic thesis, expressed in the first part of the Constitution, is that the principles that inspire the latter must be sought "in the general order of nature, in the immense system of created beings". 158

It is thanks to nature that everything lives and moves. ${ }^{159}$ If you want to judge a Constitution and its principles, you will have to consider whether these principles reflect the laws of physical nature. ${ }^{160}$

Why is the first part of the Constitution mandatory, while the second part must be subordinate and "obey" the first? There are two reasons. The first reason is that, thanks to the application of the first part of the Universal Constitution, society acquires important prerogatives: rights, freedom, independence and sovereignty. ${ }^{161}$ The second reason is that only the strict application of the principles can guarantee the stability of the established social order and avoid revolutionary crises, which are intended to break it down. Dobruska thus comes to an important conclusion:

We can then affirm that a people that does not want to expose itself to revolutionary crises, or submit to the sword of despots, must hurry to establish and recognize the inviolable authority of the first part of a veritable Constitution; if the people will submit to such a point [i.e. to the first part of the Constitution], thus subordinating the second part in such a way that it [i.e. the second part] will be nothing more than the enactment [of the first] and its guarantee; once such a regime is assured, the people will no longer have to fear revolutions, nor foil conspiracies, nor break down tyrants, because one part of the Constitution will be the guarantee of the other. ${ }^{162}$

157 Ibidem, 53.

158 Loc. cit. [C'est dans l'ordre général de la nature, dans l'immense système des êtres créés, qu'il faut chercher la première partie].

159 Loc. cit.

160 Ibidem, 54.

161 Ibidem, 58.

162 Ibidem, 58: [Nous pouvons donc affirmer, qu'un peuple qui ne veut point s'exposer aux crises révolutionnaires, ou se livrer au glaive des despotes, se hâtera d'instituer et de reconnồtre l'inviolable autorité de cette première partie de toute véritable Constitution; et qu'il lui subordonnera tellement la seconde, qu'elle n'en sera jamais que l'émanation et la garantie; bien assuré qu'avec un tel régime, il n'aura ni révolutions à craindre, ni complots à déjouer, ni tyrans à détruire, puisque toujours une partie de sa Constitution sera la garantie de l'autre]. 
Our author also reminds us that the first part of the Constitution is nothing more than an elementary code, in which the legislator finds his frame of reference for legislating, while the people draw from it indications for sanctioning the laws, drawn up by the legislator himself.

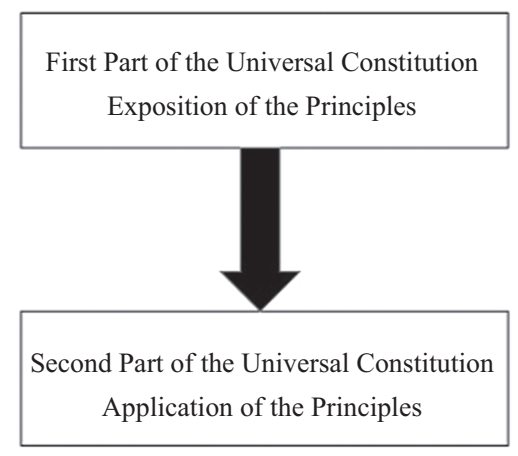

Fig. 2: Essence and Form of the Universal Constitution.

Source: author.

According to Dobruska, the promulgation of laws by the legislator must respect the hierarchy of regulatory sources. It starts from the basic principle of the Constitution, which is the principle of self-conservation and the happiness of individuals (le Principe). From this principle arise the other principles, which concern the different thematic areas addressed in the Constitution (freedom, equality, education, sovereignty, the legislative and executive body, etc.). The law must be based on the ultimate principle (Fig. 3).

According to Dobruska, "laws are not, and must not be, but the guarantee of freedom and equality, or the right to exercise all efforts aimed at achieving supreme happiness in society". 163

In a democratic society, the people are given the right and the power to control the content of laws, which may be passed or rejected by them. The right of the people lies in verifying that the laws are in conformity with the ultimate principle, i.e. self-conservation, with all the principles elaborated in the Universal Constitution, and with the rights that derive from these same principles. Only through this process of continuous monitoring and verification of legislation is it possible to achieve the ultimate goal of society: the happiness and prosperity of citizens.

163 Ibidem, 89: [Les loix ne sont donc et ne doivent être que la garantie de la liberté et de l'égalité, ou du droit de l'exercice de tous ses efforts, pour atteindre le suprême bonheur dans la société]. 


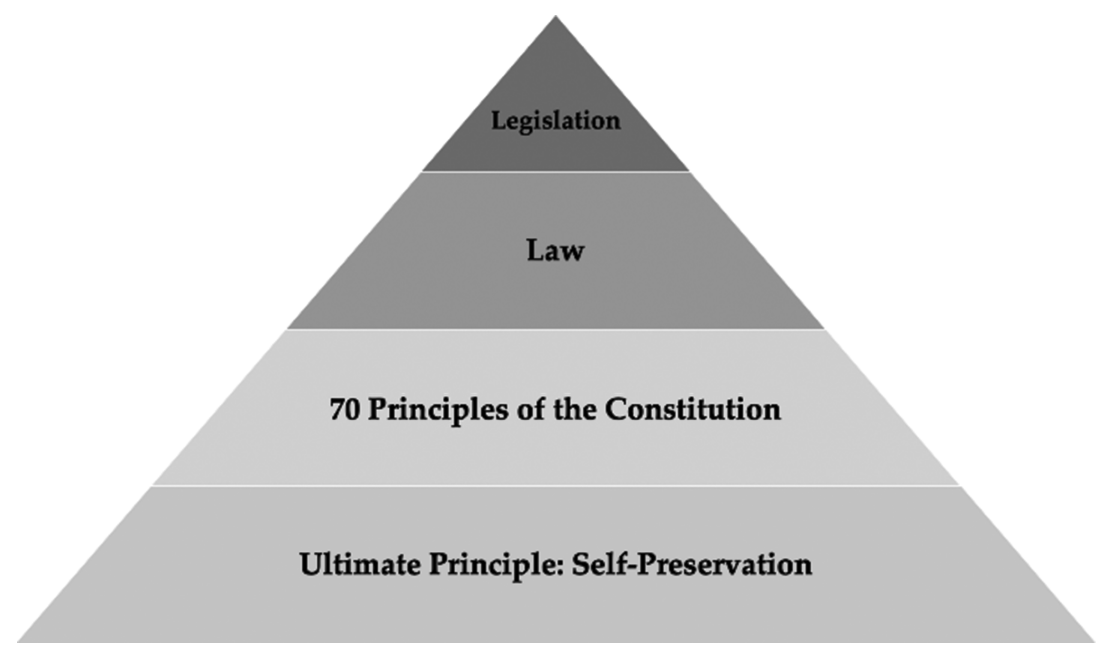

Fig. 3: Hierarchy of the Sources of Law according to the Universal Constitution of Dobruska. Source: author.

But how does the people verify that the ultimate principle and the principles of the Universal Constitution are respected by the laws? How does the people know these principles? Dobruska proposes a solution:

Now, the process of bringing the people to this knowledge is very simple. The different definitions of the principle and of the law that can result from it, will be written on a tablet, in the form of commandments. This tablet will be displayed both before the eyes of the people, in the popular sections, and before the eyes of the legislators, in the national assembly. Each law will be preceded by an explanatory notation of the right on which it is based. Looking at the table, the people judge the truth or falsehood of the explanatory notation, and the consequence of it. The people then grant or refuse to grant that law, with their decision preceded by an explanatory notation, as the legislator has done, of whether they accept or reject what has been proposed. ${ }^{164}$

164 Ibidem, 59-60: [Or, pour amener le peuple à cette connoissance, le procédé est bien simple. Sur un tableau toujours exposé aux yeux du peuple dans les sections populaires, comme aux yeux des législateurs dans l'assemblée nationale, seront écrites en forme de commandement les diverses définitions du principe et du droit qui peut en résulter. Chaque loi étant précédée d'un considérant explicatif du droit, sur lequel elle se fonde. Le peuple en jettant les yeux sur le tableau, juge de la vérité ou de la fausseté du considérant, et de la conséquence qu'on en a tirée ; dès-lors il accorde ou refuse sa sanction, en faisant, ainsi que le législateur, précéder sa décision d'un considérant, soit qu'il accepte ou qu'il refuse]. 
As we can see, the ultimate principle (self-preservation) and the seventy principles of the Universal Constitution that derive from the analysis of the various thematic nuclei of the Constitution (freedom, equality, etc.) are to be considered as real "commandments written on a table, exposed to the people in the popular sections and to the legislator in the national assembly".

One cannot but notice the similarity with the commandments dictated, according to the biblical account, by God to Moses on the tablets of the law. Now it is no longer God who dictates the commandments to the legislator but nature, through acute observation, which aims to be scientific and truthful, based as it is on the reason that regulates physical reality. The principles, contained in the first part of the Constitution, are equivalent to truths, which cannot be called into question.

That these principles should not be questioned is very well understood by the generation that lived (and often suffered) under the Ancien Régime. This generation subsequently fought for the French Revolution and identified itself with it, ${ }^{165}$ even women ${ }^{166}$ and children.

But what will happen when the revolutionary crisis is over? How will it be possible to guarantee that the following generations can still believe with conviction and passion in the principles of the Universal Constitution, without letting themselves be distracted or enchanted by some "meddlesome person of their time, possessor of the mystery" and believing in him instead? This kind of case presents a risk of returning to the pre-revolutionary starting point. Dobruska wonders about the prospects of the order that came out of the revolution.

In order to avoid a return to the past, future generations will have to be taught the first part of the Constitution, which contains "stable and precise definitions, clear and well-argued ideas on freedom, equality, the sovereignty of the people, powers, principles, and rights". ${ }^{167}$

\section{Ibidem, 65.}

166 Ibidem, 64. This is unfortunately the only time that Moses Dobruska mentions women and puts them on the same level as children. Historical literature shows that women - starting with Olympe de Gouges (1748-1793), who drew up the famous Declaration of the Rights of Woman and the Female Citizen in 1791 - played an important role in the French Revolution. See, for example, Erica Joy. Mannucci, Baionette nel focolare. La Rivoluzione francese e la ragione delle donne, (Milano: Franco Angeli, 2016).

167 Ibidem, 66: [Il nous faut donc dans cette première partie de la constitution, des définissions stables et pré-cises, des idées claires et bien développées, sur la liberté, sur l'égalité, sur la souveraineté du peuple, sur les pouvoirs, sur les principes et sur le droit; idées sans le secours desquelles on ne pourra jamais décider justement ce que sont et ce que doivent être les loix]. 
These ideas and principles form the basis of the laws to be enacted by the legislator. So future generations will not only feel these principles with emotion but will also know ${ }^{168}$ them. In fact, the healthy truth "penetrates into the heart and spirit. It warms the sensitivity of one [heart] and the understanding of the other [spirit]. It lives with both of them in an eternal bond of love and trust. This is the prerogative of the healthy truth". ${ }^{169}$

It is still not enough for the first part of the Constitution to be taught to the next generation with passion and intellectual rigor. Dobruska recommends that ideas and arguments be written simply and in precise language: clear, and not as obscure as the language used by philosophers. It must be written in a convincing way: only in this way can the Constitution serve the young, the next generation, as an elementary and catechetical book. Only in this way will the youth be educated and socialized - we would say today - according to this "religion of principles". According to Dobruska, "light will be drawn from it instead of the formulas of a creed, conviction instead of mysteries, duties instead of sacraments". ${ }^{170}$

According to our author, an example of an unclear and confusing argument is a famous sentence from the Social Contract of Jean-Jacques Rousseau. As is well known, the Geneva philosopher writes in his work: "Man is born free; and everywhere he is in chains". ${ }^{171}$ According to Dobruska this sentence is unclear. Which man is Rousseau talking about? The one in the natural state or the social man? He cannot have in mind the man in the state of nature, who we know to be free. Does he mean the man who lives in society? If this were the case, however, the statement would be likewise obscure because in the state of culture man was certainly not born free, but strongly dependent on others. ${ }^{172}$ Criticism

\footnotetext{
168 Ibidem, 67.
}

169 Ibidem, 68: [La saine vérité pénètre à la fois dans le cœur et dans l'esprit; elle échauffe la sensibilité de l'un en frapant l'entendement de l'autre, et vit avec tous deux dans une liaison éternelle d'amour et de confiance; tel est l'apanage de la saine vérité].

170 Ibidem, 72: [Elle y puiseroit la lumière au lieu de formules de croyance, la conviction au lieu de mystères, et les devoirs au lieu de sacremens].

171 Rousseau, Du contrat social, I. 1. 3 (Idem, The Social Contract, 5).

172 Dobruska, Philosophie sociale, 70-71: [De quel homme parle-t-il? de l'homme dans l'état de nature, ou de l'homme social? Il ne peut avoir en vue l'homme de la nature, celui-là n'est point dans les fers. Il parcourt aujourd'hui librement comme autrefois les forêts. Il cherche sans contrainte sa boisson et sa nourriture. Est-ce de l'homme social que veut parler l'immortel philosophe? alors comment concevoir que celui-ci peut être considéré comme né libre? Il est né dépendant et très - dépendant. Quelle serait son existence future dans la société s'il demeuroit sans éducation, et ses facultés sans développement; enfin, si absolument informe, il 
is not so much directed at the principle theorized by Rousseau, which Dobruska has understood perfectly and with which he agrees, but at the lack of clarity and precision of the sentence.

According to Dobruska, Rousseau should have formulated his principle in this way:

Man in the state of nature is free and independent like all other animals. Nature has provided him with an instinct, which is sufficient for him in an independent regime; he has then joined in society, and in the whole known world, we find the man who lives with his fellow men. In this more or less developed union, needs have increased proportionally. Almost everywhere, the more the culture of instinct was perfected, the more advantage was taken of it to oppress man and tighten the limits of his dependence; and he is everywhere in chains. ${ }^{173}$

As we shall see later, individuals in society are no longer autonomous, as was the case in the natural state, but increasingly dependent on each other. However, as Rousseau thought, this does not mean that they should not be free, always in chains or unhappy. In order to achieve happiness in society, it is necessary that laws based on constitutional principles are correctly applied and that the people are vigilant and control the work of the legislative body. This is the main task of the people: to watch over, "in a scrupulous way and with sincerity, the preservation of the first part of the Constitution". ${ }^{174}$

The constitutional principles elaborated by Dobruska are based, as it emerges more clearly in the following, on the knowledge and the acute observation of the human soul and behavior, but also on observations of nature and the natural order from which they draw inspiration. For this reason, constitutional principles are, first and foremost, statements of truth, ${ }^{175}$ from which we can derive the rules governing social life. They therefore represent, for the

devoit être élevé dans l'état de pure nature, et destiné, à jouir de l'indépendance animale, cette destination même dépend tout-à-fait du vœu de ses parens ou de ses tuteurs].

173 Ibidem, 71-72: [L'homme dans l'état de nature est libre et indépendant comme tous les autres animaux. La nature l'a pourvu d'un instinct, qui lui suffisent dans un régime indépendant; il se réunit après en société, et dans tout le monde connu, nous trouvons l'homme vivant en société avec ses semblables. Dans cette réunion plus ou moins développée, les besoins augmentèrent proportionnellement. Presque partout, plus la culture de l'instinct se perfectionnoit, plus on en tiroit avantage pour opprimer l'homme et-serrer les liens de sa dépendance; et il est partout dans les fers].

174 Ibidem, 60: [un peuple qui veille avec scrupule et sincérité à la conservation rigoureuse de la première partie de sa Constitution].

175 Loc. cit.: [nous devons nous hâter de prévenir les idées, que pourraient faire naître ce tableau uniquement destiné à contenir l'énonciation des vérités, qui sont la base de la Constitution]. 
legislator, guides for the promulgation of laws. Dobruska wonders: "Are the principles the only infallible guides, then? Of course!"176

In the first part of the Constitution, Dobruska proposes an in-depth analysis of individuals and society, through the lenses of the social philosopher and sociologist. Seventeen chapters analyze a number of key issues in order to reach, at the end of each chapter, the relative "principles", that is to say the rules or norms of action that the legislator will have to apply, through the promulgation of laws, in order to achieve the ultimate goal of the Universal Constitution: the happiness and prosperity of citizens and of the whole of society.

Our author bases his analysis both on philosophical literature by ancient and pre-modernthinkers, as well as his contemporaries, and on the direct observation of nature and men.

\subsubsection{The Seventy Principles of the Universal Constitution}

The seventy principles that Dobruska distills from popular philosophical-social and sociological analysis are set out in seventeen chapters, dedicated to the following themes:

- man

- social contract

- principle, rights and selfishness

- morality of the individual

- morality and immorality of society

- the right of the strongest and the right to deception

- law, power, and body of law

- sovereignty

- public contributions

- administration

- liberty

- equality

- education

- penalties and offences

- the unity of interest

- democracy, aristocracy, monarchy, representative democracy

- conclusion

176 Loc. cit.: [Les principes sont donc les seuls guides infaillibles? Sans doute]. 
For the sake of clarity, we have listed all seventy principles in the second appendix, while in the following they will be presented in a discursive and concise manner.

\subsubsection{Social Functions of the Universal Constitution}

Before examining the new themes and their principles in more detail, it is worth summarizing what has been said so far. The functions of Dobruska's Universal Construction are essentially threefold.

The first function is that of a primary vehicle for social education, which teaches citizens how to live and interact in society, with their peers and with political institutions. Today we would call this civic education. The first part of the Constitution nourishes and improves people, because it educates them and gives them a profound knowledge of how to live together, so that there will be no abuse of power and freedom will dominate.

The nourishment that the Universal Constitution can offer is not only that its study touches feelings and transmits knowledge. It also indicates a clear orientation for life in society, which brings well-being to all individuals.

These are real benefits which individuals have in a democratic society. And these real advantages derive from the fact that the Universal Constitution affords to men the possessionof rights, such as, for example, the right to freedom, equality, freedom of religion, and private property.

This brings us to the second fundamental function of the Universal Constitution, that of conferring citizenship. All individuals living in a democratic society based on the Constitution are always citizens, i.e. people with citizenship rights.

It is unthinkable that in a democratic society there is a division between being men and being citizens, as was the case during the absolutist monarchy of the Ancien Régime. Human beings interact with each other. Throughout their lives, some people progress more than others in different areas of social action - in their spiritual and intellectual lives and in economic prosperity. Nevertheless, they still belong to the same category, the human race. We read in the Philosophie sociale:

It is therefore clear that the first part of the Constitution is nothing more than a social education, which provides an instrument, based on law, according to which man must live with his fellow human beings in society, without being changed in his essence by this association, that is, remaining the same, without becoming a being of another kind. 
This false and counter-natural distinction characterizes instead the monarchic and tyrannical system, which has established the division between man and citizen. ${ }^{177}$

The fact that the status of citizens always belongs to the human being is one of the cornerstones of the Universal Constitution of Dobruska:

Does man cease to be such just because he lives in society? Living in society is only a state of improvement and refinement. Is it possible to assume that man loses the enjoyment of his rights because he finds himself living with his fellow men, in order to develop and perfect the natural advantages of each other? The purpose of his association is nothing more than to enjoy human rights, together with those of a citizen, that is to say, of a cultured man. ${ }^{178}$

It must be stressed that, for Dobruska, every individual in a democratic state must always be a citizen, that is to say, a holder of rights. Furthermore, all citizens must enjoy the same rights.

Dobruska's harsh criticism of the absolutist monarchy of Louis XVI of Bourbon, guillotined on January 21, 1793, is clear. Under the monarchy of Louis XVI, French society, which in 1780 included about 28 million people, was mainly agrarian and strongly stratified, with little upward social mobility. The upper social classes and the centers of political and spiritual power revolved around the monarchy and its court, and included the nobility and the clergy. At a lower level of social stratification was the so-called "third estate", which contained peasants and members of the upper middle class alike. The final step of the social stratification was occupied by the peasant serfs. In the eighties of the eighteenth century, there were still about half a million serfs in France, mainly in France-Comté and Nivernais. ${ }^{179}$ In the countryside, there was a subsistence agricultural economy for farmers' families, not a rural market economy.

177 Ibidem, 74: [Il est donc évident que la première partie d'une Constitution n'étant purement qu'une éducation sociale, laquelle ne donne que le moyen fondé en droit d'après lequel l'homme doit vivre en société avec ses semblables, sans être changé dans son essence par cette association, sans qu'il soit possible qu'il ne reste pas le même être, ni qu'il puisse devenir un être d'un autre genre, cette distinction fausse et contre nature ne peut être que le système du monarchisme et de la tyrannie, qui ont établi ce système de distinction et de division entre l'homme et le citoyen].

178 Ibidem, 74-75: [Car pour vivre en société, l'homme cesse-t-il d'être homme ? L'état social n'étant pour lui qu'un état d'amélioration et de perfection, peut-il perdre la jouissance de ses droits d'homme, parce qu'il s'est réuni avec ses semblables pour développer et perfectionner mutuellement ses avantages naturels? tandis que son association n'a pour but que de jouir de ses droits d'homme réunis avec ceux de citoyen, c'est-à-dire, d'homme cultivé].

179 Peter McPhee, A Social History of France 1780-1914 (New York: Palgrave, 2004), 10 (I ed. 1992). 
Membership of a social class was not usually acquired on merit, since only in exceptional cases could a person be ennobled. Almost always, it was a status ascribed by birth. The rights and privileges of a legal and fiscal nature, or linked to a specific French territory, depended on social hierarchy and wealth, but also on personal identity. ${ }^{180}$ In eighteenth century France, the majority of the population was Catholic: those belonging to other faiths were discriminated against. Think, for example, of the strong restrictions on the civil rights of Protestants (who could marry only after obtaining a license from the sovereign), or the poll tax for Jews. ${ }^{181}$ Consequently, depending on the position they occupied in the social stratification in the Ancien Régime, some enjoyed many fiscal and legal rights and privileges compared with others who had none at all, such as peasant serfs.

In a monarchic or tyrannical regime, human beings are treated as unequal, and a distinction is made between man and citizen:

[. . . ] this distinction, false and against nature, can only belong to a monarchic or dictatorial regime, which has established this system of separation between man and citizen. But the reason is well understood: wanting to get rid of human rights, the despots hurry to banish man from society. On the one hand, human rights, on the other hand, those of the citizen. It is understandable that tyrants are more comfortable separating something that cannot be separated. ${ }^{182}$

The Universal Constitution of Dobruska aims to abolish the possibility of great privileges and enormous inequalities in rights between individuals, thanks to its guarantee of freedom, understood - and we will see later - as equality of rights. To this end, the duty of reciprocity between human beings and popular sovereignty must be affirmed.

Democratic society, to which the social philosophy of Dobruska aspires, is based on constitutional principles and laws, which guarantee equal rights for all citizens. In such a society, everyone must contribute as much as they can to the common good. No one can be excluded any more.

180 McPhee, A Social History of France 1780-1914, 38.

181 Ibidem, 43.

182 Dobruska, Philosophie sociale, 74: [. . .] cette distinction fausse et contre nature ne peut être que le systême du monarchisme et le la tyrannie, qui ont établi ce systême de distinction et de division entre l'homme et le citoyen. Mais on en conçoit bien la raison; c'est qu'étant gênés par les droits de l'homme, les despotes se hâtèrent de bannir l'homme de la société. Delà les droits de l'homme et ceux du citoyen. On conçoit que les despotes étoient bien plus à leur aise, séparant ainsi une chose qui ne pouroît eus séparée]. 
Finally, the last function of the Universal Constitution is to avoid social disorganization and the re-emergence of tyrants or the reaffirmation of a monarchic regime. As we have seen, if the legislator, under the strict control of the people, meticulously applies the principles of the first part of the Constitution, abuse of power and rebellion can be avoided. In this way, the stability of the social order is not endangered.

\subsubsection{The Purpose of the Universal Constitution}

As we shall see in more detail below, the ultimate aim of the Universal Constitution is the happiness of citizens and society as a whole. It is now necessary to focus on the principles that follow from this. The starting point in such a discussion can only be a definition of the human being.

Dobruska questions the nature, the aspirations, the desires, the needs of the human being, whom he calls the "new sovereign", the nouveau souverain, both in the state of nature and in that state of culture, that is, in society.

The first general definition, from which the Philosophie sociale starts, is that of être-homme, ${ }^{183}$ that is to say of a human being. This is a dynamic living being in transformation, capable of evolving and reaching the highest material, cultural, and spiritual peaks. In fact, the human being must be understood as "a living being, whose instinct is susceptible to the widest development and the greatest perfection". ${ }^{184}$

Dobruska goes on to say that "this definition presents us with man in all his scope, from the cradle of brute instinct, so to speak, to the highest degree of his culture and his virility".

It is an anthropological vision, which "endows man with knowledge, virtue and happiness in the same way as error, vice and unhappiness". In addition to having the greatest faculties to evolve, improve, and reach the highest degree of perfection in the most diverse areas of intellectual, moral, and material life, man is also capable of harmful and destructive actions.

This philosophical reflection on man's possibility of perfecting himself is certainly not new. It is part of a theoretical perspective widespread among the

183 Ibidem, 82.

184 Loc. cit. [Nous définirons généralement l'être-homme. L'être-homme est un être vivant dont l'instinct est susceptible du développement le plus étendu et de la plus grande perfection. Cette définition nous présente l'homme dans toute son étendue, depuis le berceau de l'instinct brut pour ainsi parler, jusqu'au plus haut degré de sa culture et de sa virilité]. 
Enlightenment thinkers of the time, which emphasised the concept of man's "perfectibility".

Although there is not complete unanimity among scholars, ${ }^{185}$ the term "perfectibility" is generally attributed to Jean-Jacques Rousseau, whose writings were well known to our Dobruska. It is in his second speech to the Academy of Dijon, on the origin and foundations of inequalities, written in 1754 , that Rousseau sets out his idea of the perfectibility of man in the civil state, compared to man in the natural or primitive state. Rousseau reminds us that the difference between man and animal lies in a specific faculty of the former, that of "perfecting oneself". More precisely, the Genevan philosopher states:

However, even if the difficulties attending all these questions should still leave room for difference in this respect between men and brutes, there is another, very specific, quality which distinguishes them and which will admit of no dispute. This is the faculty of selfimprovement, which, by the help of circumstances, gradually develops all the rest of our faculties, and is inherent in the species as in the individual: whereas a brute is, at the end of a few months, all he will ever be during his whole life, and his species, at the end of a thousand years, exactly what it was the first year of that thousand. Why is man alone liable to grow into a dotard? Is it not because he returns, in this, to his primitive state; and that, while the brute, which has acquired nothing and has therefore nothing to lose, still retains the force of instinct, man, who loses, by age or accident, all that his perfectibility had enabled him to gain, falls by this means lower than the brutes themselves? ${ }^{186}$

Dobruska assumes that man can improve and perfect his human nature, that he retains the potential for change in himself, even though his soul is very complex, made up of lights and shadows.

185 Gianluca Dioni, "Perfectibilité e perfectio. Rousseau e Wolff, armonie e dissonanze," in La filosofia politica di Rousseau, eds. Giulio Maria Chiodi and Roberto Gatti (Milano: Franco Angeli, 2012), 151.

186 Jean-Jacques Rousseau, Discours sur l'origine et les fondements de l'inégalité parmi les hommes (Amsterdam: Chez Marc-Michel Rey, 1755), 31: [Mais, quand les difficultés qui environnent toutes ces questions laisseraient quelque lieu de disputer sur cette différence de l'homme et de l'animal, il y a une autre qualité très spécifique qui les distingue, et sur laquelle il ne peut y avoir de contestation, c'est la faculté de se perfectionner; faculté qui, à l'aide des circonstances, développe successivement toutes les autres, et réside parmi nous tant dans l'espèce que dans l'individu, au lieu qu'un animal est, au bout de quelques mois, ce qu'il sera toute sa vie, et son espèce, au bout de mille ans, ce qu'elle était la première année de ces mille ans. Pourquoi l'homme seul est-il sujet à devenir imbécile? N'est-ce point qu'il retourne ainsi dans son état primitif, et que, tandis que la bête, qui n'a rien acquis et qui n'a rien non plus à perdre, reste toujours avec son instinct, l'homme reperdant par la vieillesse ou d'autres accidents tout ce que sa perfectibilité lui avait fait acquérir, retombe ainsi plus bas que la bête même?] (Idem, A Discourse on a Subject proposed by the Academy of Dijon, in The Social Contract, 184-185). 
He mentions in this regard already on the cover of his work the second verse of An Essay on Man, by the English poet Alexander Pope (1688-1744), published in 1733-34. ${ }^{187}$ In the second epistle of the poem, Pope writes:

\footnotetext{
Know then thyself, presume not God to scan;

The proper study of mankind is man.

Plac'd on this isthmus of a middle state,

A being darkly wise, and rudely great

With too much knowledge for the Sceptic side,

With too much weakness for the Stoic's pride,

He hangs between; in doubt to act, or rest;

In doubt to deem himself a God, or Beast
}

Although it is written in verse, in reality it is a philosophical essay, which gave Alexander Pope a great reputation and influenced many thinkers of the seventeenth century, including René Descartes (1596-1650), Blaise Pascal (16231662) and Samuel von Pufendorf (1632-1694). The $18^{\text {th }}$-century Enlightenment also drew inspiration from it, and traces of Pope's text can be found, among others, in Georges-Louis de Buffon (1707-1788), Denis Diderot (1713-1784), Rousseau, and Anne Robert Jacques Turgot (1727-1781).

In fact, it's no accident that Dobruska quotes Pope on the cover of the Philosophie sociale. He is joined to the English poet by a common cognitive project, that of investigating, in an impartial manner, the human soul, to understand all its facets. A search that also extends to the contradictions, the sublime, and the most miserable aspects of man, in the desire to discover what can bring him happiness. In a nutshell, this attention to the complexity of human nature and its dual character, which extends from the highest good to the lowest evil, are to be found in fifteenth-century humanism and, in particular, in the Oratio de hominis dignitate of Count Giovanni Pico della Miarandola (1463-1494). ${ }^{188}$

In his Oration on the Dignity of Man, Giovanni Pico affirms:

Neither a fixed abode nor a form that is thine alone nor any function peculiar to thyself have we given thee, Adam, to the end that according to thy longing and according to thy judgment thou mayest have and possess what abode, what form, and what functions thou thyself shalt desire. The nature of all other beings is limited and constrained

within the bounds of laws prescribed by Us. Thou, constrained by no limits, in accordance with thine own free will, in whose hand We have placed thee, shalt ordain for

187 Alexander Pope, An Essay on Man. Epistle I-IV (London: J. Wilford, 1733-1734).

188 Silvana Greco, "Heresy, Apostasy, and the Beginnings of Social Philosophy. Moses Dobruska reconsidered,” Materia giudaica 20-21 (2015-2016), 458. 
thyself the limits of thy nature. We have set thee at the world's center that thou mayest from thence more easily observe whatever is in the world. We have made thee neither of heaven nor of earth, neither mortal nor immortal, so that with freedom of choice and with honor, as though the maker and molder of thyself, thou mayest fashion thyself in whatever shape thou shalt prefer. Thou shalt have the power to degenerate into the lower forms of life, which are brutish. Thou shalt have the power, out of thy Soul's judgment, to be reborn into the higher forms, which are divine. ${ }^{189}$

Instead of the mystical ascent suggested by Pico, Dobruska, who is influenced by the esprit of the time, conceived the perfection of man as the development of intellectual and material desires (Begehrungsvermögen, in his original German draft), which can only be achieved in society, thanks to social interactions with others. His theory combines the concept of Rousseau and partly that of Wolff. Rousseau, in fact, had already pointed out in his Discourse on the Origin of Inequality how the improvement of the human intellect is supported and spurred on by passions, which lead to new knowledge. Behind passions, man's deep needs are often hidden beyond the primary ones, which for Rousseau are nourishment, sexuality, and rest:

The passions, again, originate in our wants, and their progress depends on that of our knowledge; for we cannot desire or fear anything, except from the idea we have of it, or from the simple impulse of nature. ${ }^{190}$

For Dobruska, both intellectual and material desires encourage man to seek perfection.

In order to achieve the highest perfection in society, however, a fundamental condition must be met: the enjoyment by every person of full citizenship. ${ }^{191}$ Only where class and rank privileges are abolished and freedom, understood as "equality of rights", is guaranteed, can man reach the highest level of culture and virility.

The term "virility" should not be understood in opposition to that of "femininity", as the stereotyped traits associated with the social construction of mas-

189 Giovanni Pico della Mirandola, Discorso sulla dignità dell'uomo, ed., Francesco Bausi (Parma: Gianda, 2003), 11 (The Renaissance Philosophy of Man, edited by Ernst Cassirer, Paul Oskar Kristeller and John Herman Randall Jr. (Chicago: University of Chicago Press, 1948): 224-225).

190 Rousseau, Discours sur l'origine et les fondements de l'inégalité, 36: [Les passions, à leur tour, tirent leur origine de nos besoins, et leur progrès de nos connaissances; car on ne peut désirer ou craindre les choses que sur les idées qu'on en peut avoir, ou par la simple impulsion de la nature] (Idem, $A$ Discourse on a Subject, 186).

191 Greco, Heresy, "Apostasy, and the Beginnings of Social Philosophy," 459. 
culinity might suggest. It is not a "gender issue", 192 but a call to "virtue", in the sense of the strength and courage to oppose the aristocrats, seen as inept and immoral.

As Antoine de Baecque reminds us, the whole political discourse in the revolutionary era hinges on two antagonistic poles: the aristocrat and the patriot. The revolutionary ideology, as often happens with any populist ideology, was also supported by a bodily policy and bodily practices. ${ }^{193}$ According to Agnès Steuckardt-Moreau, the attributes of the aristocrat were essentially three: "degeneration, the grotesque, and the mask", while the patriot was characterized "by hygiene, virility, and luminosity". ${ }^{194}$ It is well known that the aristocrats paid particular attention to the care of their bodies, making considerable use of makeup, wigs and perfumes. ${ }^{195}$ In addition, they paid a lot of attention to their clothes, with their bright colors and precious fabrics.

The fighter for the French Revolution and for the ideals of freedom, equality and brotherhood, on the other hand, was a completely different person, and far from the aristocrat, who lived in a degenerate and embellished way. A new masculinity emerged, based on courage, strength, work and the elimination of male coquetry. This is the man whose intrinsic perfectibility will be promoted by the Universal Constitution, in Dobruska's intentions, in a democratic, free and virile way.

192 Although women played a non-marginal role at the time of the French Revolution, Moses Dobruska, unlike other thinkers such as Condorcet, does not devote any specific reflection to women, let alone to their often deplorable condition.

193 A. de Baecque, Le corps de l'histoire. Métaphores et politique, 1770-1800 (Paris: CalmannLevy, 1993).

194 Agnès Steuckardt-Moreau, Endormeur chez Marat (1790-1792), in INALF, Dictionnaire des usages socio-politiques (1770-1815) (Paris: Klincksieck, 1989) 87-110, esp. 89: [On repère dans la figure de l'aristocrate trois attributs: 'la dégénérescence, le grotesque et le masque' tandis que l'idéal corporel que représente le patriote se caractérise par 'l'hygiène, la virilité, et par la luminosité].

195 Audrey Robin, Une sociologie du beau sexe. L'homme et les soins de beauté de hier à aujourd'hui (Paris: L'Harmattan, 2005). 